ICIP WORKING PAPERS:

2015/03

Does military pressure boost fiscal capacity? Evidence from late-modern military revolutions in Europe and North-America

Oriol Sabaté Domingo

\title{
INSTITUT
}

CATALÀ

INTERNACIONAL

PER LA PAU 


\section{Does military pressure boost fiscal capacity? Evidence from late-modern military revolutions in Europe and North-America}

Oriol Sabaté Domingo 


\section{Institut Català Internacional per la Pau}

c/ Tapineria 10, 08002 Barcelona

T. +349355442 70 | F. +34935544280

recerca.icip@gencat.cat | http://www.icip.cat

\section{Editors}

Oriol Sabaté Domingo

\section{Editorial Board}

Pablo Aguiar, Laia Balcells, Alfons Barceló, Gema Collantes-Celador, Caterina Garcia, Abel Escribà, Tica Font, Antoni Pigrau, Xavier Pons, Mònica Sabata, Jaume Saura, Josep Maria Terricabras and Léonie Van Tongeren

\section{Typesseting}

Ātona Víctor Igual, S. L.

\section{ISSN}

2014-5793 (online edition)

\section{DL}

B. 10.189-2015

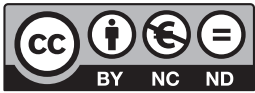




\section{AUTHOR}

Oriol Sabaté* holds a degree in Economics from the Pompeu Fabra University, a Master's degree in Globalization, Development and Cooperation from the University of Barcelona, and also in Economic History (University of Barcelona, Universitat Autònoma de Barcelona and University of Zaragoza). His doctoral thesis deals with the current conditions and consequences of military spending in the long term in Spain.

Contact: Oriol.Sabate@ub.eduedu

\section{ABSTRACT}

Warfare and military competition have been defined as important driving forces for the expansion of fiscal capacity during late-modern times. However, the empirical evidence remains inconclusive, and we still lack a historical narrative that explains how warfare has affected the evolution of late-modern fiscal systems. This paper aims to fill this gap by analysing the effects of warfare on fiscal development in the light of the so called 'Revolutions in Military Affairs' (RMA) that took place in Western countries since the mid- $19^{\text {th }}$ century to the present. The results suggest that the interplay between warfare and fiscal expansion has followed an inverted ' $U$-shape' pattern, in which changes in military tactics and technology have pushed public revenues up until the destructive power has passed the nuclear threshold level. Additionally, the results pose that politics is relevant to complete this warled narrative, despite having been neglected in most of the previous quantitative literature.

* This paper is part of my PhD dissertation project, carried out under the supervision of Alfonso Herranz and Sergio Espuelas, to whom I am most grateful for their valuable advice. I acknowledge the financial support from the Catalan International Institute for Peace and the Catalan Department of Economy and Knowledge, as well as the Research Project ECO2012-39169-Co3-03. This paper has been presented at the Economic History PhD seminar of the University of Barcelona and the XI International Congress of the Spanish Association of Economic History, and I thank the participants for their comments. 



\section{CONTENTS}

1. INTRODUCTION

2. THE INTERPLAY BETWEEN WARFARE AND FISCAL EXPANSION 10

3. REVOLUTIONS IN MILITARY AFFAIRS' SINCE THE MID-19TH CENTURY

4. DATA ON PUBLIC EXPENDITURES AND REVENUES

5. STRUCTURAL BREAKS IN TOTAL AND DIRECT TAX REVENUES 29

6. THE PERMANENT EFFECTS OF WARFARE ON FISCAL DEVELOPMENT

6.1. THE ROLE OF POLITICAL REGIMES IN FISCAL PERSISTENCE

6.2. THE ROLE OF CIVILIAN AND MILITARY EXPENDITURES IN FISCAL PERSISTENCE

7. CONCLUSIONS

REFERENCES

ANNEX A. DATA

ANNEX B. LIST OF MAJOR WARS 



\section{INTRODUCTION}

Shortly before the end of the First World War, the Austrian economist Joseph Schumpeter (1918) argued in his famous article "The Crisis of the Tax State" that, during the early-modern period, growing warfare expenses forced sovereigns to pile up debts and to progressively expand the tax system. Following these preliminary Schumpeterian insights, recent historical studies have defined military competition as one of the most important driving forces for the expansion of fiscal capacity in early-modern times. The main line of argument suggests that the persistent technological change and the growing size of armies experienced since the Infantry Revolution of the $14^{\text {th }}$ century made war increasingly costly. This forced governments to improve their long-term taxation capacity and their access to public debts in order to provide better military endowments and to pay off the heavy financial burdens inherited from wartime. ${ }^{1}$

Similar arguments have been applied to late-modern fiscal history, even though the dynamics of the interplay between warfare and fiscal development are less clear. In one of the earliest quantitative analysis on this topic, Rasler and Thompson (1985) concluded that global wars gave place to permanent increases in public revenues (as a percentage of GDP) in a sample of major powers during the 19th and the 2oth centuries. According to these authors, the persistence of higher public revenues after global wartimes was led by the pressure exerted by non-war expenditure, which was a response to the new social problems, domestic coalitions and bureaucratic organizations that emerged after the war. Other authors have also found a positive interplay between major warfare and permanent increases of public revenues, even though the dynamics of the persistence have been generally

1. Historical research on this topic has inspired a growing theoretical literature that analyse the links between warfare, fiscal capacity and economic performance. See, for instance, Besley and Persson (2009), Dincecco and Prado (2012). 
overlooked (Jaggers, 1992; Besley and Persson, 2009; Dincecco and Prado, 2012). ${ }^{2}$

This paper argues that the outburst of major wars has effectively shaped the long-term evolution of public revenues in late-modern times, but provides a new theoretical approach in order to better understand the interplay between warfare, military pressure and fiscal expansion. To do so, the paper exploits the so called 'Revolutions in Military Affairs' (RMA) that took place in late modern times in the Western countries (i.e. Western Europe, the US and Canada). The RMA are usually defined as periods of innovation in which military forces develop new tactics, doctrines, procedures and technological engines. According to military historians, the Western countries' warfare has experienced at least four major RMA since mid- $19^{\text {th }}$ century, concretely the Land Warfare and Naval Revolutions (1850-1913), the Interwar Revolution (1914-1945) and the Nuclear Revolution (since about 1945). These key processes transformed the nature of warfare and shaped the costs of military conflicts.

I argue that these RMA have determined the evolution of late-modern public revenues in the Western countries. Concretely, warfare increased its pressure on fiscal systems during the so called Land Warfare and Naval Revolution, and even more during the Interwar Revolution, as new major wars required higher material and human resources over time. By contrast, the unprecedented destructive capacity of the Nuclear Revolution diminished the pressure of warfare on fiscal systems, as major military conflicts among great powers became politically unacceptable. Military spending continued to put pressure on fiscal systems as states kept preparing themselves for future conventional warfare, but the absence of new major boosts in military spending prevented additional increases in the level of public revenues related to the outburst of wars. In summary, the interplay between warfare and fiscal expansion followed an inverted ' $U$-shape' pattern, in which changes in military tactics and technology pushed

2. See Dincecco (2009) and Aidt and Jensen (2009) for less straightforward results on the role of warfare on permanent changes in total and direct tax revenues respectively. 
public revenues up until the destructive power passed the nuclear threshold level.

The paper addresses this topic by analysing a new international dataset on public expenditure and revenues for a set of ten European and North American countries from the mid- $19^{\text {th }}$ century to the present. The results, based on structural break tests and regression analysis, are largely consistent with my hypothesis. Moreover, the results pose that politics is relevant to complete this war-led narrative, despite having been neglected in most of the previous literature. Concretely, autocracies appear to favour persistence in public revenues during the Interwar Revolution compared to democratic countries due to their militaristic policies. On the contrary, democracies strengthened persistence after the Second World War due to their higher engagement with non-military purposes compared to autocratic regimes. Lastly, democracies also appear to enforce persistence in direct taxes during the Interwar Revolution compared with autocratic regimes, which reflect their higher engagement with progressive taxation.

The paper proceeds as follows. Section 2 and 3 review the previous literature on warfare and fiscal capacity, and the main 'Revolutions in the Military Affairs' that took place during the $19^{\text {th }}$ and the $20^{\text {th }}$ centuries respectively. Section 4 presents the new dataset, and section 5 analyses the growth and the persistence of public revenues in each country of the sample by applying structural break tests. Section 6 analyses the incidence of military pressure on the growth of fiscal capacity by applying regression analysis, and Section 7 concludes. 


\section{THE INTERPLAY BETWEEN \\ WARFARE AND FISCAL \\ EXPANSION}

The Austrian economist Joseph Schumpeter published in 1918 his famous article "The Crisis of the Tax State". There, the author described the difficult financial straits suffered by the Reich and the other powers of today's Austrian territory during the $14^{\text {th }}$ and $15^{\text {th }}$ centuries. According to him, "the most important cause of the financial difficulties consisted in the growing expenses of warfare", mainly due to the "emergence of mercenary armies" to confront the larger Turkish forces. The princes reacted by getting indebted and negotiating new taxes on behalf of the "common exigency". Out of this "common exigency" the tax system developed and helped to create the so called "tax state". ${ }^{3}$

This Schumpeterian "tax state" concept has inspired a growing literature that analyses the evolution of fiscal systems in modern times, in which military competition and the increasing cost of warfare play a prominent role. For instance, Kersten Krüger (1987), who formally characterized the "tax state" in terms of its ability to levy regular taxes and to raise loans, considered the growing military forces and the expanding administration as the main causes of the $16^{\text {th }}$ century crisis of state finances and the opening up of new sources of revenues. More recently, Bonney and Omrod (1999) expanded this line of argument by differentiating between "tribute state", "domain state", "tax state" and "fiscal state". Once again, they described the origins of the "tax state" as a "consequence of military developments", in which taxation was "reactive, driven by expenditure, especially expenditure on war". ${ }^{4}$ The increasing size of the armies and the technological innovations in

3. Schumpeter (1918), pg. 13 .

4. According to the authors, the "tax state" was different from the "domain state" in that a larger proportion of the ruler's revenue came from regular and quasi-permanent taxes (among other distinctive features). 
the fields of military and naval armaments led to "escalating military costs which spiral out of control in periods of sustained warfare". The response was an increase on regular direct and indirect taxes, as well as a conversion from short-term to long-term loans guaranteed by the state..$^{5}$

This prominent role of warfare on the development of modern tax systems has also been emphasised by authors such as the historical sociologist Charles Tilly (1990) and the military historian Geoffrey Parker (2010), who argue that technological changes and the growing size of the armies since the expansion of the gunpowder and the defence artillery in early-modern times made war more destructive and costly over time. The changing character of warfare gave military superiority to those states that were able to sustain large and permanent armies equipped with modern technologies, what forced European governments to appeal increasingly to long-term credits and taxes. ${ }^{6}$ Since early-modern states were mainly devoted to warfare and kings' prestige, the increasing costs of military competition became a powerful stimulus to expand the sources of public revenues and to evolve to more sophisticated fiscal structures. ${ }^{7}$ Those fiscal expansions undertaken during wartimes persisted in post-war times due to the incentives of governments to provide better military endowments and to the heavy financial burdens inherited from wartime.

Similar arguments have been applied to late-modern fiscal history, even though the results are less conclusive. In one of the earliest key contributions, Peacock and Wiseman (1961) argued that the First and Second World Wars brought about a permanent displacement effect

5. As has been argued by Patrick K. O’Brien (2011), those states that improved their capacity to tax in early-modern times also increased their capacity to borrow loans. According to the author, borrowing money during wartime was critical for waging war, as revenues from taxes and domains flowed slowly but the need for payments to armed forces was generally urgent. In this context, credits and long-term loans could be obtained, as time went on, "by way of anticipation of inflows of tax revenues".

6. Several authors link military competition, technological improvement and fiscal expansion with the rise of Europe and the emergence of the "great divergence" (Parker, 2010; Hoffman, 2012).

7. See also Hoffman and Rosenthal (1997), Yun-Casalilla (2010). 
on British public expenditures due to the social acceptance of higher levels of public taxation. Similarly, in a quantitative analysis on the evolution of public revenues in a sample of major powers (France, Japan, United Kingdom and United States) during the $19^{\text {th }}$ and the $20^{\text {th }}$ centuries, Rasler and Thompson (1985) conclude that global wars (but not minor interstate wars) gave place to permanent increases in public revenues (as a percentage of GDP). The authors suggest that the persistence of higher public revenues after global wartimes was led by the pressure exerted by non-war expenditures, which were a response to the new social problems, domestic coalitions and bureaucratic organizations that emerged after the war. ${ }^{8}$

Other authors have further extended this kind of analyses to broader datasets, even though they have not always addressed the reasons behind the persistence of higher post-war revenues. For instance, Jaggers (1992) analysed the intensity of warfare in a dataset of European and American countries. The author concluded that inflated levels of resource mobilization in international military conflicts (measured as the total number of battle deaths) and the 'societal trauma' caused by civil wars (measured by a combination of the number of battle deaths per 10.000 inhabitants and the political outcome of the war) led to increasing post-war state revenues per capita. From a different empirical strategy, Besley and Persson (2009) and Dincecco and Prado (2012) argue that late-modern and early-modern wars are positively correlated with present fiscal capacity (measured, among other variables, by the average of the current share of taxes over GDP) in broad international datasets. Finally, Dincecco, Federico and Vindigni (2011) find a positive correlation between higher levels of military spending and taxation in the Italian states during the Risorgimento.

However, unlike the studies on the early-modern period, these analyses do not address the changing character of warfare and its po-

8. Similarly, Obinger and Petersen (2014) argue that relevant welfare policies developed after the two world wars were actually set up during wartimes (and even during the phase of war preparation), when governments needed to ensure a healthy and loyal population. 
tential consequences in terms of fiscal development. Warfare has been generally characterized as a homogeneous and pure exogenous variable. As a consequence, to what extent the transformation in the nature of warfare has shaped the evolution of fiscal systems remains unexplored. This approach has limited our understanding of the precise relation between warfare, military pressure and fiscal expansion, as warfare has been a changing phenomenon in late-modern times. Additionally, most analysis do not address to what extent the persistence of fiscal changes has been related to military or to non-military spending. Actually, even if civil expenditures have become by now preponderant in public budgets, ${ }^{9}$ military spending might have been relevant in the historical evolution of fiscal development.

Moreover, other authors have raised some doubts about the real effects exerted by warfare in the late-modern public budgets. For instance, Dincecco (2009) finds a small negative effect of warfare (measured by average military deaths per conflict year) on current per capita revenues from the mid-17th century to the outburst of the First World War. The author argues that wars might have exerted a negative effect on fiscal development due to the destruction that they caused, even though he also recognises that some of the main positive breaks in the series of public revenues fit with military conflicts. From another perspective, other authors do not agree on the alleged new public civilian duties appeared due to wartimes. For instance, Fontvieille (1976) concluded that the two World Wars did not gave place to higher public expenditures in France once military spending and war-related costs are excluded from the accounts. Similarly, Broadberry and Howlett (1998) argued that the Second World War did not bring about major increases in social expenditures in Great Britain, while Broadberry and Harrison (2005) conclude that the First World War did not end up with major increases in civilian expenditures (once debt services are excluded).

9. The unprecedented growth of the public provision of productive and social goods since the 19th century onwards has been well-established by economic historians. See, for instance, Lindert (2004) and Espuelas (2014). 
Lastly, some authors have also explored the effect of warfare on direct tax revenues, but with unclear results. In this regard, Besley and Persson (2009) conclude that those countries that were more engaged in international wars in late-modern times ended up with a higher share of direct taxes within total public revenues. On the other hand, Aidt and Jensen (2009) observe that the establishment of temporary income taxes often coincided with the outburst of wars, as happened in the United States during its Civil War (1861-65), in the Austrian Empire during its war against Sardinia (1848-49) or in Denmark during its wars against Prussia (1848-49 and 1864). However, they do not find any significant correlation between warfare and permanent income taxes, and conclude that the financial pressures created by war might have caused the establishment of emergency tax innovations rather than lasting income tax reforms. 


\section{REVOLUTIONS IN MILITARY AFFAIRS' SINCE THE MID-19TH CENTURY}

The literature on warfare and fiscal capacity in early-modern times generally links changes in military tactics and technology with higher pressures on public budgets during wartimes. Military historians have classified the most critical military changes in the so-called 'Revolutions in Military Affairs' (RMA). According to Murray and Knox (2001), the RMA are periods of innovation in which military forces develop new tactics, doctrines, procedures and technological engines. In spite of its name, the RMA generally require long-term periods to be developed and consolidated, and end up changing the ways wars are carried out. Parker (2010) describes them with the biological concept of 'punctuated equilibrium', in which short periods of significant changes are followed by long-term periods of gradual and slow adjustments. Even though most of the studies concerning the late-modern period have generally neglected these changes, I argue that the analysis on the interplay between warfare and fiscal development should take these changes into consideration in order to characterize the dynamics of this relationship.

Krepinevich (1994) and Rogers (2000) document ten major RMA in modern times. These started with the Infantry Revolution of the $14^{\text {th }}$ century (in which the infantry, together with the British archers and the Swiss pikemen, displaced the prominent role of the cavalry) and ended recently with the Nuclear Revolution of the mid- $20^{\text {th }}$ century. Since the mid- $19^{\text {th }}$ century, these authors identify four basic RMA, namely, the Land Warfare Revolution, the Naval Revolution, the Interwar Revolution and the Nuclear Revolution. Tilly (1990) characterizes this whole period as the 'age of specialization', in which military forces became a powerful specialized branch of the national government and the division of labour between armies and police sharpened. 
The Land Warfare Revolution can be seen as a direct inheritance from the French and the Industrial Revolutions. According to Knox (2001), the French Revolution established new tactical battlefield approaches based on almost universal conscription and the intensification of firearms power (particularly by the mobile artillery). Concurrently, the Industrial Revolution placed newly abundant resources in the hands of governments and provided outstanding war technological innovations. According to Murray and Knox (2001), the Industrial Revolution first influenced the Crimean War (1853-56), where the rifled muskets, the telegraphy and the steamships let British and French armies to defeat the numerically superior Russian forces. Nevertheless, it was not until the American Civil War (1861-65) that the new industrial technology and mass mobilization were clearly combined. The military historian Mark Grimsley (2001) describes the American conflict as a total war that prefigured the forthcoming First World War, in which both sides devoted their full destructive energies against each other. The Union and Confederacy armies supplied their vast troops by railroad and steamships, connected distant units with telegraph lines, motivated soldiers and civilians with ceaseless propaganda (combined with coercion) and enhanced their firepower with rifled muskets, breech-loading rifles and improved artillery.

Krepinevich (1994) considers therefore the American Civil War as the starting point for the development of the Land Warfare Revolution, which lasted for the following fifty years..$^{10}$ The three major European wars in 1859, 1866 and 1870-71 also involved the use of some new military technologies and tactics on the battlefield, mainly due to Helmuth von Moltke's doctrines within the Prussian army, although they did not extend the war mobilization to the level of the American Civil War (Showalter, 2001). ${ }^{11}$ These land warfare advances went

10. Similarly, Onorato et al. (2013) argue that mass mobilization spread thanks to the extension of the railway network in the second half of the $19^{\text {th }}$ century rather than immediately after the French Revolution.

11. For instance, even though both the Crimean War (1853-56) and the Franco-Prussian War (1870-71) were shaped by innovative military technologies (such as the minié rifle bullet and the steamships during the Crimean War, or the French chassepot rifle and the Prussian breech-loading cannon during the Franco-Prussian War), none of these 
along with changing tactics and technology in the naval battlefield. From the mid- $19^{\text {th }}$ century to the First World War, the former wooden ships powered by wind and armed with short-range cannons gave way to metal-hulled ships powered by turbine engines and armed with long-range rifled artillery. The preliminary French naval innovations of the mid-1840s were quickly responded by the British Navy, which ultimately found in the unified Germany its most serious challenger. The HMS Dreadnought (1906) coincided with the (uneasy) introduction of the submarine and the development of the torpedo. Herwig (2001) additionally highlights the reorganization of the British naval stations and the updating of the officials' training in accordance with the new strategy to confront the German threat.

As it has been said, the First World War combined, with the highest ferocity and mortality, both industrial firepower and logistics with mass mobilization. According to Bailey (1914), warfare in 1914 was still a lineal affair, with doctrines that emphasized flank attacks and envelopment tactics. These doctrines led to physical encounters of masses of infantry and cavalry supported by artillery firing directly at short range. The new mass armies sustained by railroads and industrial economies during the First World War closed the flanks, so that new tactics had to be developed to focus on breaking the enemy front and destroying its backward forces. Indirect fire and technical improvements in aerial observation, photography and ballistic calculus, were some of the keys of the new warfare doctrine. Due to the huge scope of these changes, Bailey (2001) argues that the development of armoured vehicles, aviation and information technologies during the following decades were just incremental improvements upon the conceptual model established during the First World War.

Black (2006, pg. 11) defines the period from 1860 to 1945 as the 'age of total war', in which "the human, ideological, and economic resources provided by population growth, nationalism, economic devel-

conflicts led to a massive recruitment of troops. Even when the Third French Republic urgently declared the general levy, the rapid incursion of Prussian forces into the French territory prevented the possibility to organize a massive army. 
opment, globalization, and imperial strength provided the wherewithal for large-scale conflict". ${ }^{12}$ Even if the process of technological, tactical and doctrinal evolution could initially lead to faster wars in favour of the best equipped armed forces, the spread of the innovations among major armies rapidly removed previous military superiorities. ${ }^{13}$ Additionally, the growth of per capita revenues and the increasing efficiency of the government agencies allowed diverting a growing share of the national output to warfare requirements without leaving the basic reproduction necessities uncovered. ${ }^{14}$ Table 1 shows the war-related deaths in several major wars in France, United Kingdom and United States since the mid-nineteenth century to the present and the maximum number of mobilized soldiers per year of war. It shows that those numbers increased throughout the period until reaching its maximum levels in the First and the Second World Wars.

Table 1. War-related deaths and mobilized soldiers per year of war in several major European and North-American wars (1850-1995)

\begin{tabular}{l|c|cc|cc|cc}
\hline & Period & \multicolumn{2}{|c|}{ France } & \multicolumn{2}{c|}{ United Kingdom } & \multicolumn{2}{c}{ United States } \\
\hline & & Deaths & Mobilized & Deaths & Mobilized & Deaths & Mobilized \\
\hline $\begin{array}{l}\text { Crimean War } \\
\text { American }\end{array}$ & $1854-1856$ & 95 & 645 & 22 & 382 & - & - \\
$\begin{array}{l}\text { Civil War } \\
\text { Franco- }\end{array}$ & $1861-1865$ & - & - & - & - & 618 & 1.063 \\
$\begin{array}{l}\text { Prussian War } \\
\text { Second Boer }\end{array}$ & $1870-71$ & 152 & 1.000 & - & - & - & - \\
War & $1899-1902$ & - & - & 22 & 521 & - & -
\end{tabular}

12. Obviously, this does not imply that all wars could be defined as 'total'. Differences in technology and manpower allowed the western countries to fight transoceanic imperial wars without having to wage global but just limited conflicts (even if for the colonized societies these could be well defined as total wars). Actually, the imperialist wars could be led by traditional military tactics, as was clearly exemplified during the battle of Omdurman (Sudan) in 1898, in which the British army undertook one of the latest cavalry charges in history. Moreover, most of the conflicts among western countries (such as the wars of German and Italian Unification) aimed just to defeat the enemy's army but not to destroy them. Only the American Civil War and the two World Wars had the kind of extensive objectives that are distinctive from 'total wars'.

13. Rogers (2000).

14. Broadberry and Harrison (2005). 
Table 1. (Continuación)

\begin{tabular}{l|c|cc|cc|cc}
\hline & Period & \multicolumn{2}{|c|}{ France } & \multicolumn{2}{c|}{ United Kingdom } & \multicolumn{2}{c}{ United States } \\
\hline & & Deaths & Mobilized & Deaths & Mobilized & Deaths & Mobilized \\
\hline World War I & $1914-1918$ & 1.385 & 5.277 & 908 & 4.430 & 117 & 2.897 \\
World War II & $1939-1945$ & 213 & 5.000 & 419 & 5.090 & 405 & 12.123 \\
Korean War & $1950-1953$ & - & - & 0,7 & 872 & 54 & 3.636 \\
$\begin{array}{l}\text { French-Indo- } \\
\text { china War }\end{array}$ & $1946-1954$ & 94 & 1.025 & - & - & - & - \\
Vietnam War & $1965-1973$ & - & - & - & - & 58 & 3.550 \\
\hline
\end{tabular}

Notes: Data from Correlates of War Project dataset. All figures are in thousands.

In line with Krepinevich (1994) and Rogers (2000), Murray and Knox (2001) conclude that nuclear weapons developed since 1945 constitute the latest RMA (particularly since 1949, when the Soviet Union was able to confront the North-American nuclear power with its own nuclear bomb). The forthcoming combination of mass weapons and ballistic missiles (which provided better effectiveness than other kind of available arm systems, while reducing the own causality rates) increased the military power of both contenders. Murray and Knox (2001) suggest that the unprecedented destructive power of nuclear and mass weapons and the peerless deathly wars that they could cause explain the prudent attitudes of major powers during the Nuclear Revolution era. ${ }^{15}$ Even though western armies did not renounce to get ready for the outburst of a conventional war (that could even end up with a nuclear conflict), warfare among nuclear nations became something to be avoided. ${ }^{16}$ As a consequence, and in line with the figures of Table 1, the Nuclear Revolution seems to have reversed the

15. This line of argument should not deny the importance of social protest and anti-war activism in democratic contexts, which raised awareness about the destructive power of nuclear weapons and contributed to made mass-killing politically unacceptable.

16. The deep technological innovations undertaken since the 1970 (mainly in ICT) and the gradual reduction of the number of soldiers have given place to new warfare tactics, while the cyber warfare (based on the virtual war in the cyberspace) and the increasing privatization of defence and security services have recently opened new military challenges. However, military analysts and historians do not agree on the revolutionary nature of these changes. See Gongora and Reikhoff (2000) for a debate on this topic. 
former pattern of harsher and increasingly costly warfare, at a time that economic resources have been also far more abundant in European and North-American economies than before.

Taking these features into account, I argue that the so called 'age of specialization' might be described as an inverted 'U-shape', in which changes in military tactics and technology pushed warfare intensity up until the destructive power passed the nuclear threshold level. I argue that this historical pattern has at turn determined the specific relation between warfare and fiscal development in Western countries. Firstly, the Land Warfare and Naval Revolution, and even more the Interwar Revolution, pushed the cost of warfare up, which at turn put more pressure on fiscal systems during and after wartimes. This pressure could be led by military spending, as governments needed to be ready for costlier wars that would demand higher military endowments and capabilities over time. Additionally, those wars that required most material and human resources could also lead to permanent changes in public revenues due to the outcome of new social coalitions and the provision of new public civilian services. On the other hand, these wars might have also pushed direct tax revenues up, as major warfare pressures governments to establish efficient but unpopular taxes that otherwise would have not been accepted by the citizens.

On the other hand, the Nuclear Revolution reversed this pattern, as no major boosts in military spending (such as those of the Interwar Revolution) would take place during the second half of $20^{\text {th }}$ century. It obviously does not mean that military spending could not be exerting an ongoing pressure on fiscal systems. Actually, the militarization of the Cold War era in a context of new industrial and costlier conventional weapons would be translated into a constant pressure to keep fiscal pressure high in historical terms. However, the absence of new major boosts in military spending would prevent new war-related displacements in the level of public revenues. 


\section{DATA ON PUBLIC \\ EXPENDITURES AND REVENUES}

To assess the historical interplay between warfare and fiscal expansion, this paper presents a new international dataset on public spending and revenues of central government for a set of European and North American countries from 1850 to $1995 \cdot{ }^{17}$ Public spending has been disaggregated into military and civil expenditures. Military spending is a comprehensive indicator of the effective pressure exerted by military activities on fiscal systems, as it reflects the financial effort done by governments on military endowments. Its main shortcoming is related to the fact that military expenditures do not cover all war costs. For example, public mobilization of civil production and distribution, interest debts related with war loans, reconstruction of damaged civil infrastructure, payment of war reparations, or indirect costs such as the opportunity costs of conscription are not included in military spending. Nevertheless, it accounts for the costs of all military services, which are clearly the bulk of the expenditures for war preparation, and can also be considered as a good basis for a comparison among the public effort undertaken in different wartimes. ${ }^{18}$

Compared with the evidence provided in this paper, previous international datasets on military spending, such as those by the Stockholm International Peace Research Institute (SIPRI), the International Institute of Strategic Studies (IISS) or the United Nations Office for

17. Central government data take into account neither the revenues nor the expenditure from regional and local administrations. Therefore, the analysis is necessarily focused on the behaviour of central public structures.

18. Rockoff (2012) provides an interesting attempt to account for the total military and civil costs of North-American wars throughout the $20^{\text {th }}$ century. However, there is still no similar data available for other countries in the long-term. Additionally, Rockoff focuses his analysis on wartimes, but does not provide similar data on the peacetime costs of wars and war preparation, such as the opportunity costs of conscription or the reparation of damaged civil infrastructures. 
Disarmament Affairs (UNODA), cover shorter time-periods. ${ }^{19}$ On the other hand, the Correlates of War Project (COW) dataset provides a long-term series since the beginning of the $19^{\text {th }}$ century to the present for a broad set of countries, but most of their historical sources and methods are not specified..$^{20}$ By contrast, my new dataset covers a long period while also clarifies the sources and the criteria used to collect the data. Most data come from secondary sources (mainly national historical statistics) and fit as much as possible with the North Atlantic Treaty Organization (NATO) methodological criterion, which is one of the most comprehensive and widespread criteria on military spending and is used by several international institutes and organizations (such as the aforementioned SIPRI and IISS). ${ }^{21}$

On the other hand, the dataset on public revenues has been elaborated on the basis of the historical statistics compiled by Brian Mitchell (1990, 2003, 2007), which account for total public revenues of central government (excluding loan receipts). Other secondary sources (mainly national historical statistics) have been used to complement Mitchell's dataset when needed. ${ }^{22}$ In order to analyse the evolution of the fiscal structure, the dataset also includes information on direct taxes, which mainly contains land, property and income taxes. Both public expenditures and revenues have been measured as a percentage of the GDP. This allows exploring the historical

19. The SIPRI probably provides the broadest military spending dataset for present times, compiling military spending data for 172 countries since 1988. Its sources come either from questionnaires sent annually to governments, from expert analyses or from other secondary sources. Its dataset is available in its webpage http://www.sipri.org/ The IISS dataset is available in http://www.iiss.org/ and the UNODA dataset in http:// www.un.org/disarmament/

20. The COW dataset is available in http://www.correlatesofwar.org/

21. According to NATO, defence expenditure is defined as payments made by a national government specifically to meet the needs of its armed forces or those of allies. It mainly includes salaries and social benefits to military personnel, operational and maintenance expenditures, procurement expenditures on equipment and other goods, expenditures on infrastructure construction, research and development, military aid to other countries and contributions to international organizations. For a methodological discussion on the NATO criterion, see Brzoska (1995) and Sabaté (2013). See Annex A for details on the sources.

22. See Annex A for details on the sources. 
evolution of these variables in terms of the total resources available in the economy. Moreover, the so-called 'military burden' (that is, military expenditures as a share of GDP) is generally considered the best way to capture the relative effort done by every country on military endowment.

Figure 1. Military expenditures and public revenues (as a percentage of GDP) in France and Germany (1850-1995)
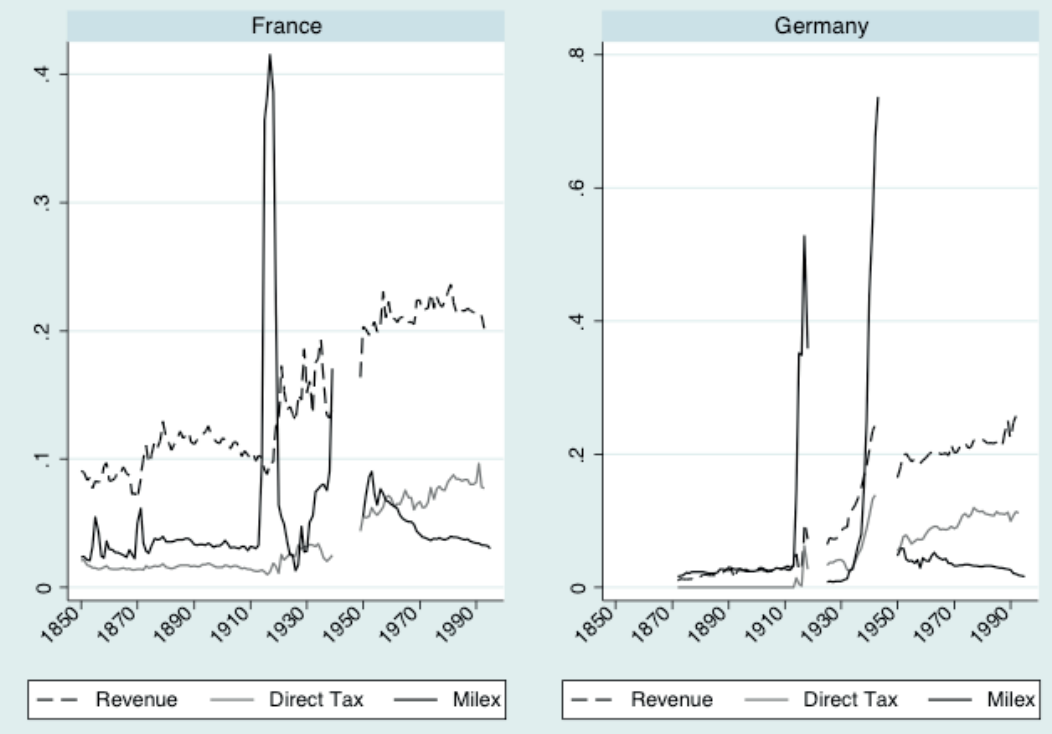

Notes: see text and Appendix A for data-sources. There is no available data for France from 1941 to 1949, and for Germany from 1919 to 1924 and from 1944 to 1949.

Figure 1 and 2 show the military burden for the four major powers of the sample (France, Germany, UK and US). The highest ratios of military burden in all countries were reached during the Interwar Revolution period, with maximum values during the outburst of the First and (particularly) the Second World War. Similar levels were only reached in the US during the Land Warfare and Naval Revolution period due to the American Civil War (1861-65). This is consistent with the description of the 
Interwar Revolution as very cost-intensive RMA in which military recent technological innovations were combined with mass armies. On the other hand, the American Civil War appears as a precedent of the subsequent total wars with a huge mobilization of capital and labour resources.

Figure 2. Military expenditures and public revenues (as a percentage of GDP) in United Kingdom and United States (1850-1995)
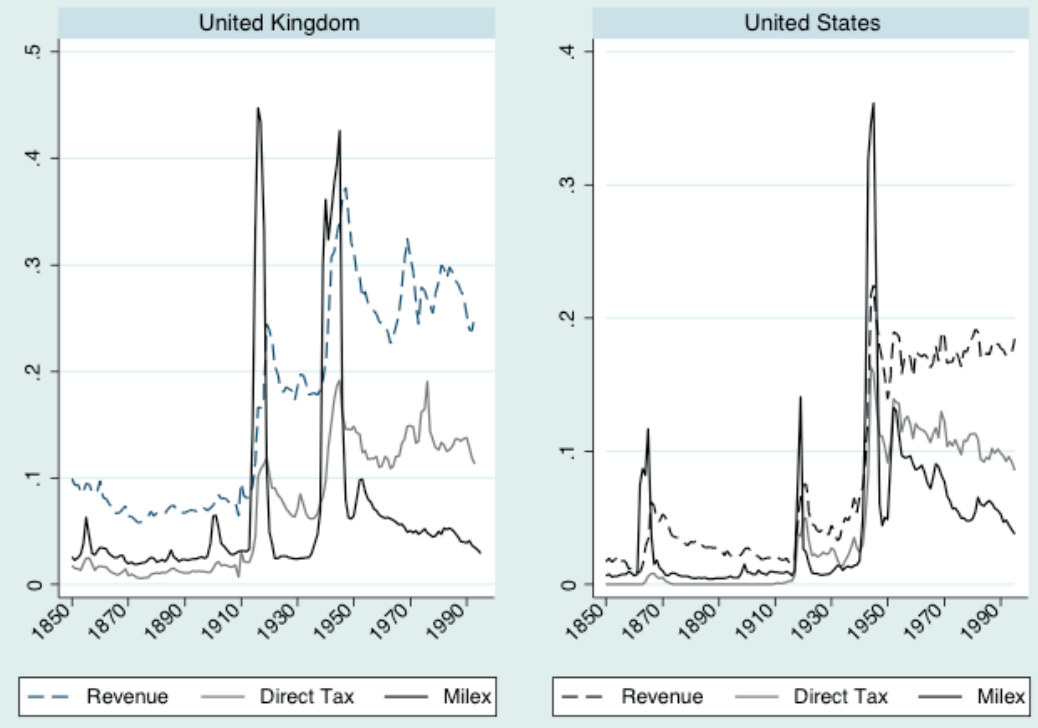

Notes: see text and Appendix A for data-sources.

By contrast, the other European continental wars and the ongoing European imperialist hostilities did not consume the same amount of resources. ${ }^{23}$ Similarly, the European and US military interventions in the so-called Third World during the Nuclear Revolution period (as well as the NATO and the UN multilateral operations, or even the Gulf War

23. The technological race undertaken during this period did not clearly lead to growing military burdens, which suggest that it was mainly supported by the extra resources provided by the process of economic growth. Eloranta (2007) raises similar conclusions when analysing military spending in a set of major combatants for the period 1870-1914. 
in 1991) did not lead to such sharp increases in military expenditures. As it has been stated above, wars that did not combine current technological innovations with mass armies did not involve massive military costs. Nevertheless, during the Nuclear Revolution period military burden ratios were much higher than the $19^{\text {th }}$ century standards (except in Germany, due to the restrictions imposed by the allied countries after the Second World War). As has been mentioned before, the harsh international tension during the Cold War era forced armies to constantly update their firepower capabilities (both their conventional and their mass destructive weapons), despite the lack of total wars among major powers. ${ }^{24}$

Figure 3. Military expenditures and public revenues (as a percentage of GDP) in Canada and Italy (1850-1995)
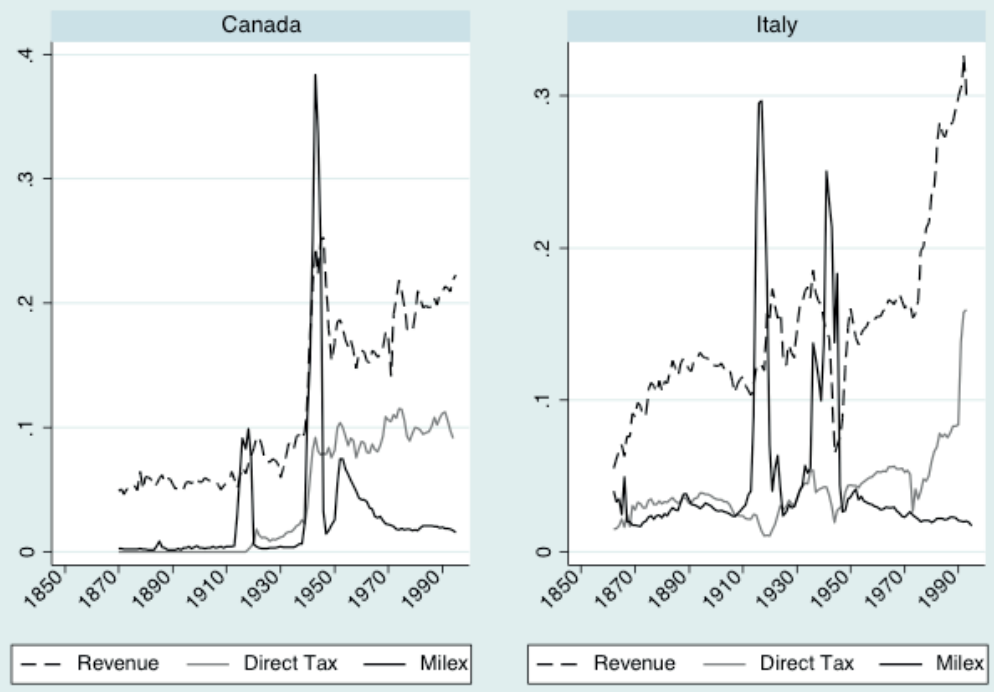

Notes: see text and Appendix A for data-sources. There is no available data for Italy from 1850 to 1861 .

24. These very high levels of military burden sustained since the Second World War also allowed some of the great powers to participate in several military conflicts without increasing dramatically their military financial efforts. 
All in all, and despite the differences among the countries of the sample, the overall picture of the three RMA episodes seems to reflect the aforementioned inverted 'U-shape', in which the Interwar Revolution brought the highest military burden ratios. Figures 3 to 5 provide the same data for the set of secondary powers (Canada, Italy, Norway, Portugal, Spain and Sweden). Most countries present lower military burden ratios (and lower volatility) than the great powers, except for Canada and Italy during the Interwar Revolution. This reflects the secondary role played by these countries in the international scenario, which spared them the need to constantly update their RMA military capabilities. Nevertheless, in line with the former major powers' trends, the maximum values for most countries are found during the Interwar Revolution period, while during

Figure 4. Military expenditures and public revenues (as a percentage of GDP) in Norway and Portugal (1850-1995)
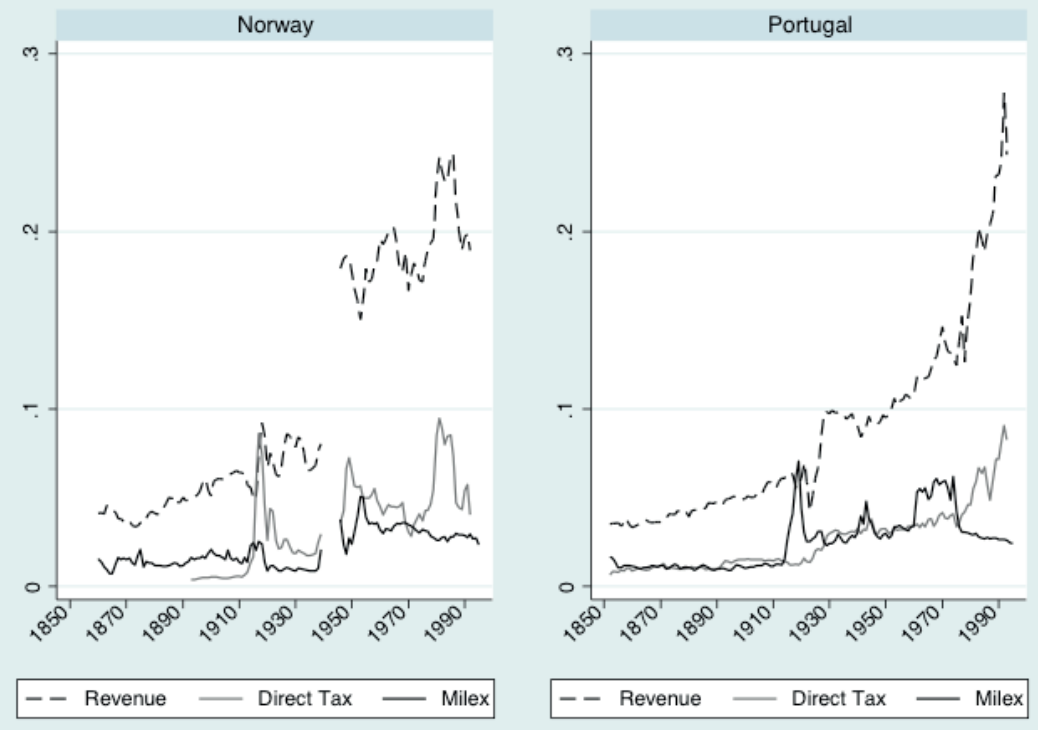

Notes: see text and Appendix A for data-sources. There is no available data for Norway from 1940 to 1945 . 
the Nuclear Revolution the ratios were initially high but decreased over time. ${ }^{25}$

Figures 1 to 5 also show the data on total and direct tax revenues. In all great powers, their highest increases took place during the Interwar Revolution period, mainly during major wartimes. By contrast, they were fairly stable during the previous period. Total and direct tax revenues (as a percentage of GDP) became stable again in France, Germany and the US after the Second World War, while total revenues fluctuated widely in the UK (although presumably not due to

Figure 5. Military expenditures and public revenues (as a percentage of GDP) in Sweden and Spain (1850-1995)
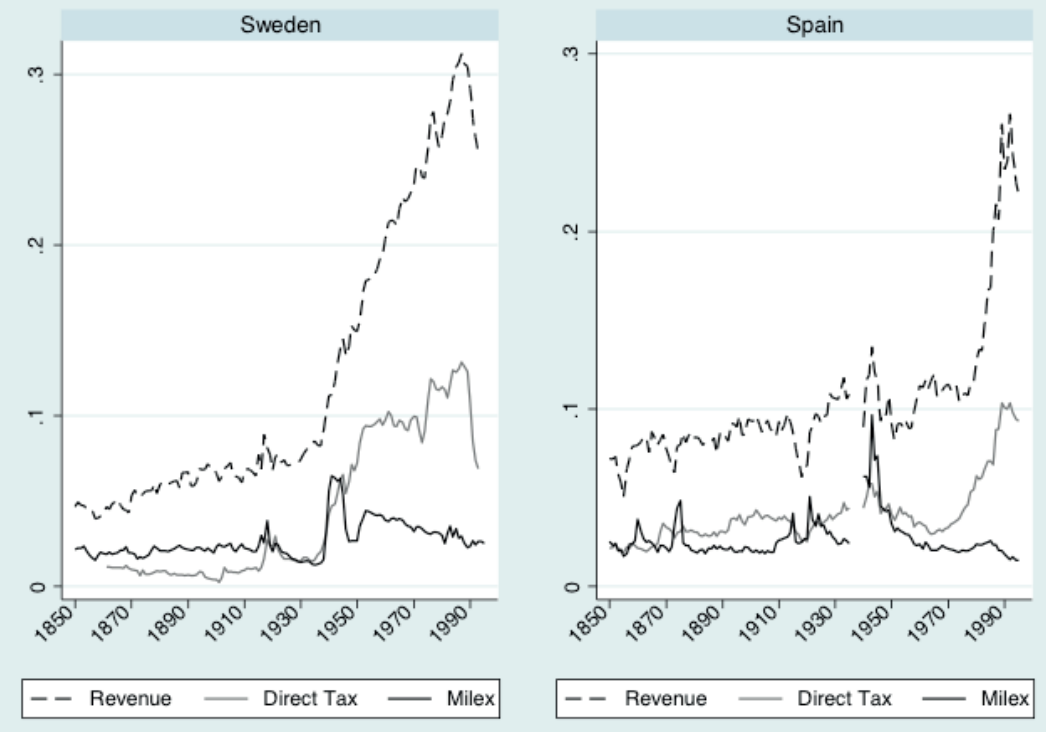

Notes: see text and Appendix A for data-sources. There is no available data for Spain from 1936 to 1939 .

25. Only Portugal shows higher values in the 1950-70 in comparison to former decades, mostly due to its colonialist war in Angola. In any case, it is still far from those maximum ratios associated to capital and labour intensive wars. 
changes in the military burden). On the other hand, some of the major increases in the total and direct tax revenues of secondary powers took place during the Interwar Revolution period too, although the evidence seems to be less homogeneous. In summary, these figures can be taken as preliminary evidence to suggest that the very intensive wars of the Interwar Revolution gave place to permanent shifts in public revenues, while other wars did not have the same impact. 


\section{STRUCTURAL BREAKS \\ IN TOTAL AND DIRECT TAX \\ REVENUES}

To start exploring the interplay between warfare and fiscal expansion, this section studies the timing of major changes in fiscal development and its degree of persistence in every country of the sample. To do so, I run a breaking point test based on Ben-David and Papell (2000), which identifies the main statistical shifts in both the intercept and the trend of a variable, regardless of whether a unit root is present or not in the series. The analysis is based on an extension of the SupF test developed by Vogelsang (1997). The test involves estimating the following regression for every possible break point:

$$
\mathrm{y}_{\mathrm{t}}=\mu+\theta_{1} \mathrm{DU}_{1 \mathrm{t}}+\beta \mathrm{t}+\gamma_{1} \mathrm{DT}_{1 \mathrm{t}}+\sum_{\mathrm{j}=1}^{\mathrm{k}} \mathrm{c}_{\mathrm{j}} \mathrm{y}_{\mathrm{t}-\mathrm{j}}+\varepsilon_{\mathrm{t}}
$$

where $\mathrm{DU}_{1 \mathrm{t}}=1$ if $\mathrm{t}>\mathrm{T}_{\mathrm{B} 1}$, o otherwise, and $\mathrm{DT}_{1 \mathrm{t}}=\mathrm{t}-\mathrm{T}_{\mathrm{B} 1}$ if $\mathrm{t}>\mathrm{T}_{\mathrm{B} 1}, \mathrm{O}$ otherwise, being $\mathrm{T}_{\mathrm{B} 1}$ every possible breaking point in the series. Equation (1) is estimated sequentially for each possible break year. The $\operatorname{SupF}_{t}$ statistic is the maximum, over all possible break-points, of twice the standard $F$-statistic for testing $\theta_{1}=\gamma_{1}=0$. For each choice of $\mathrm{T}_{\mathrm{B} 1}$, the value of the lag length $k$ is selected according to the criteria suggested by Campbell and Perron (1991). Following Ben-David and Papell (2000), I have set the upper bound of $k$ at 8 and the criterion for significance of the t-statistic on the last lag has been set at 1.60 .

Ben-David and Papell (2000) extended this procedure to allow for multiple breaking points. The equation to be estimated is the same as equation (1) but allowing for two additional dummy variables:

$$
\mathrm{y}_{\mathrm{t}}=\mu+\sum_{\mathrm{i}=1}^{\mathrm{k}} \theta_{1} \mathrm{DU}_{1 \mathrm{t}}+\beta \mathrm{t}+\sum_{\mathrm{i}=1}^{\mathrm{k}} \gamma_{1} \mathrm{DT}_{1 \mathrm{t}}+\sum_{\mathrm{j}=1}^{\mathrm{k}} \mathrm{c}_{\mathrm{j}} \mathrm{y}_{\mathrm{t}-\mathrm{j}}+\varepsilon_{\mathrm{t}}
$$


where $m$ is the number of breaking points. When $m=1$, the expression is the same as the Vogelsang equation. When $m=2$ the procedure becomes a test of one-break null against a two-break alternative. This time, $\mathrm{DU}_{2 \mathrm{t}}=1$ if $\mathrm{t}>\mathrm{T}_{\mathrm{B} 2}, \mathrm{O}$ otherwise, and $\mathrm{DT}_{2 \mathrm{t}}=\mathrm{t}-\mathrm{T}_{\mathrm{B} 2}$ if $\mathrm{t}>\mathrm{T}_{\mathrm{B} 2}, \mathrm{O}$ otherwise. $\mathrm{T}_{\mathrm{B} 1}$ is fixed by the year chosen by estimation of the onebreak model. Equation (2) is estimated sequentially for each potential break year $\left(\mathrm{T}_{\mathrm{B} 2}\right)$, and the $S u p F_{t}$ statistic is calculated as described above. Critical values have been taken from Ben-David and Papell (2000), who account for until five breaks with 120 observations. As usual in stability tests, the first and last years of the sample have not been included in the testing procedure. Here I have limited the sample to $0.1 \mathrm{~T}<\mathrm{T}_{\mathrm{Bm}}<0.9 \mathrm{~T}$, with a required separation between break dates of at least 10 years.

Tables 2 and 3 present the results for both the total and the direct tax revenues (the two of them as a percentage of GDP). Several breaks fit with the outburst or the end of major wartimes. ${ }^{26}$ Regarding the total revenues, two World Wars are associated with significant and positive breaks in Canada, France, Norway and the US, while France and the US also show positive breaks during the Franco-Prussian War and the American Civil War respectively. All those breaks took place during wartimes characterized by significant budgetary efforts, with the only possible exception of Norway during the Second World War, for which military burden data is not available. ${ }^{27}$ Similarly, Canada, France and the US experienced their main breaks in direct tax revenues during the two World Wars (although in the case of France it came once the First World War was finished), which again led to persistently higher revenue levels.

26. No significant results have been found in the UK for total revenues, as well as in Germany, Norway and the UK for direct tax revenues, due to the persistent volatility of the series.

27. Grytten (2014) argues that the Norwegian boost in fiscal pressure after the Second World War was carried out by the Labour Party's government (in power since 1935), which took the opportunity to maintain the levels of public expenditures established in the country during the Nazi occupation (well above the historical spending ratios). 


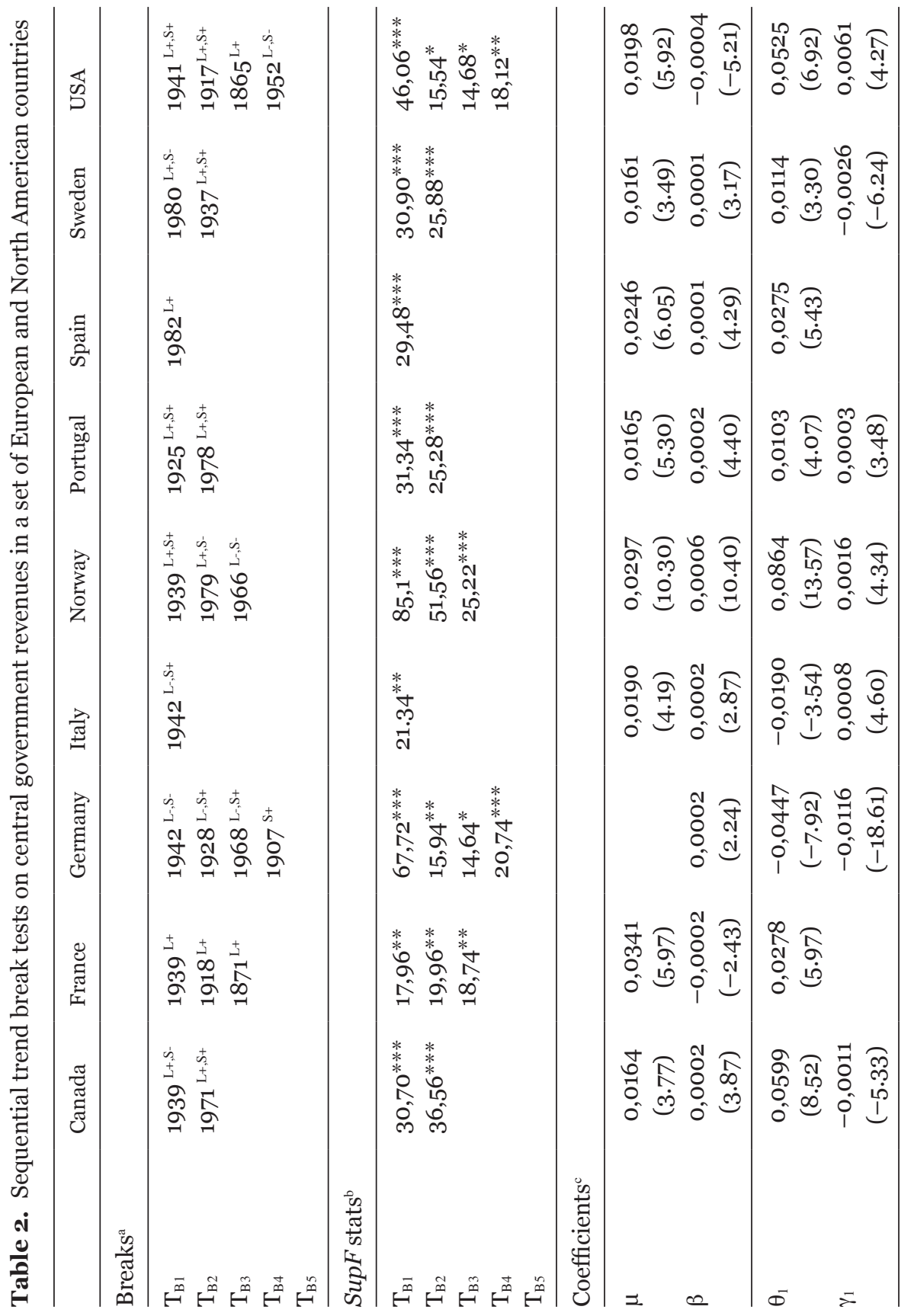




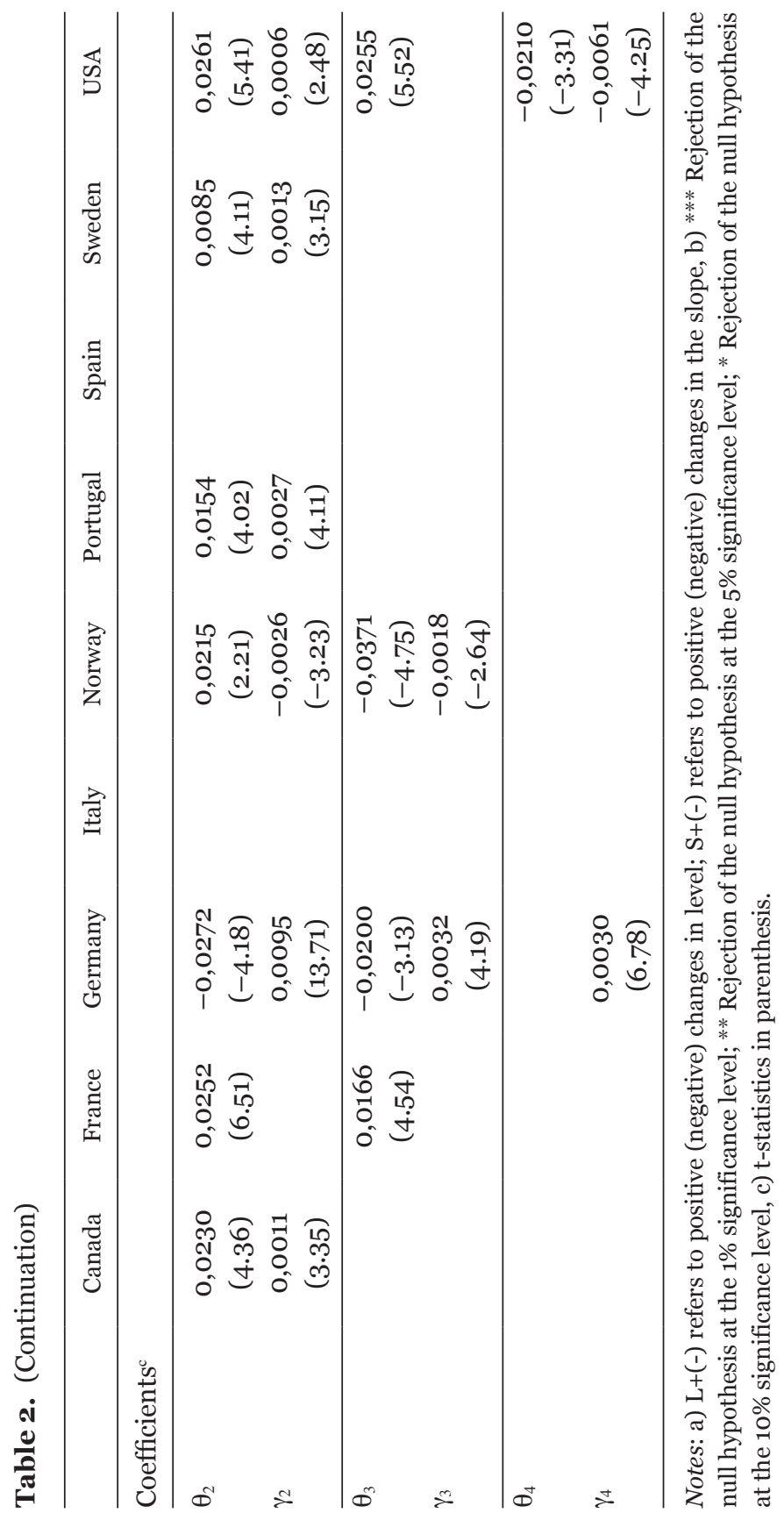




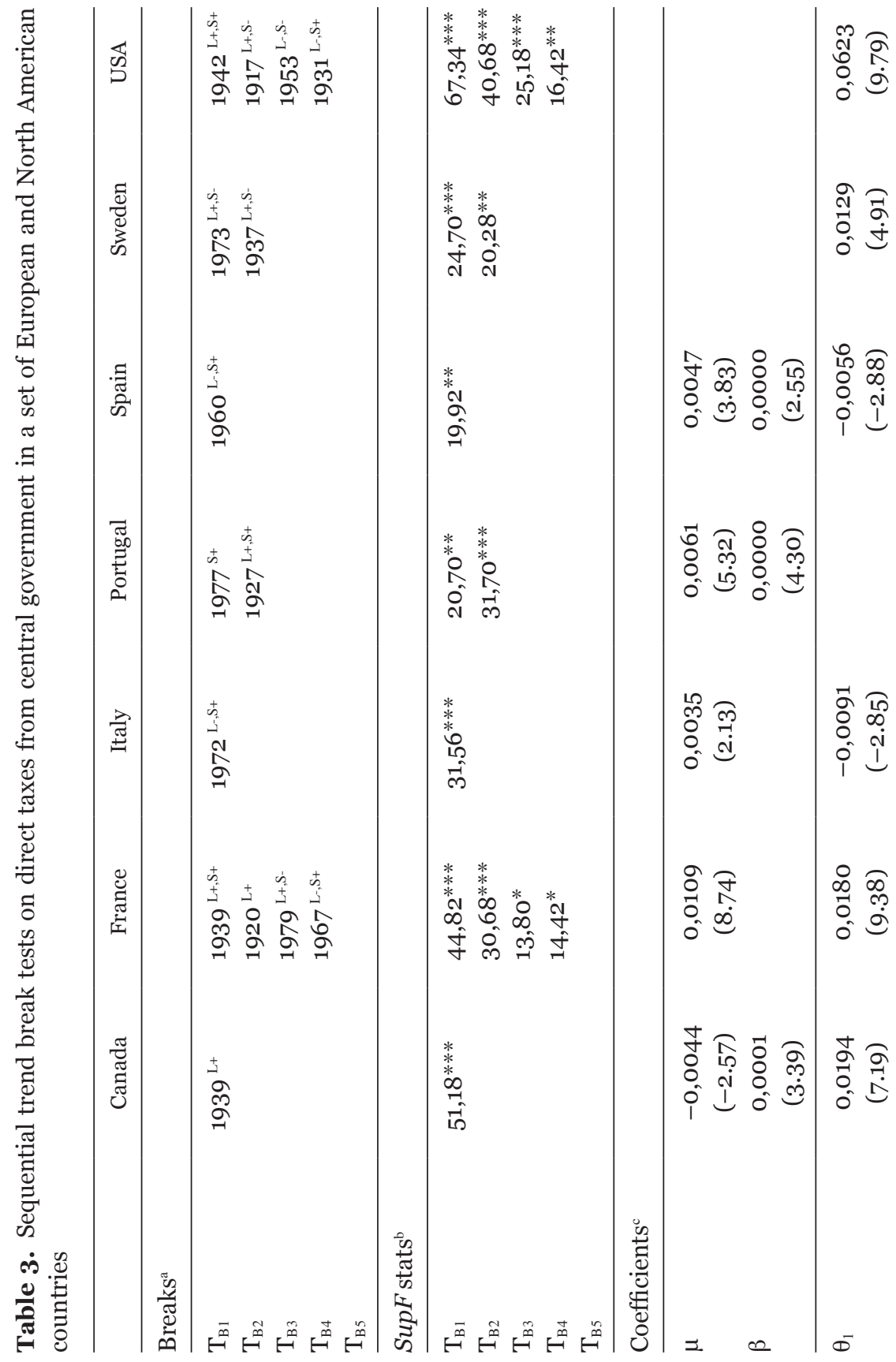




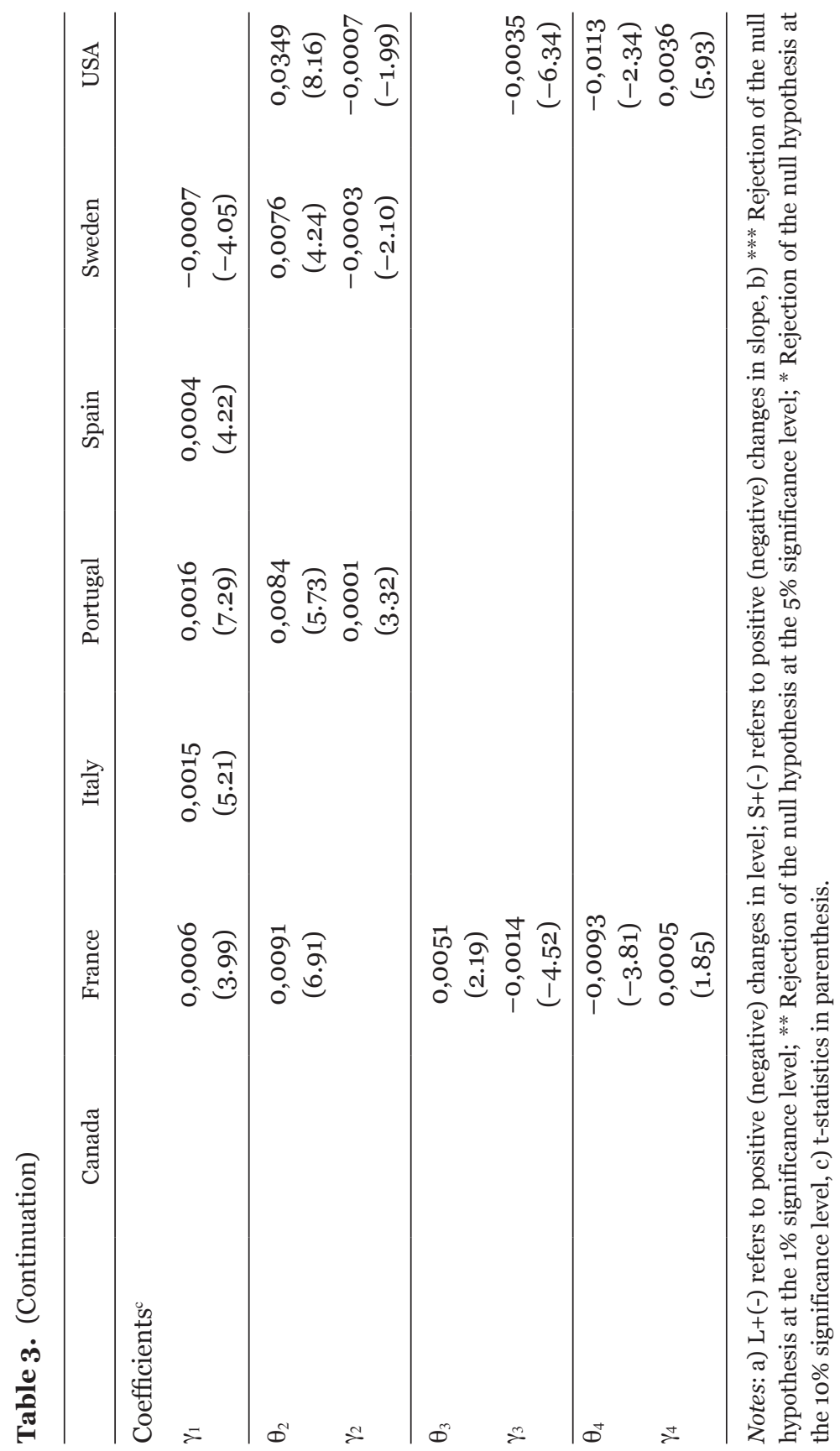


All in all, this set of results mainly fits with the aforementioned inverted 'U-shape', in which major permanent increases took place during the Interwar Revolution's wartimes, while most of the other wars undertaken during the previous or subsequent RMA did not gave place to such fiscal displacements. By contrast, in Germany and Italy total revenues suffered negative changes in levels during the Second World War, which reflects the higher pre-war levels sustained by the two countries, in comparison with their subsequent evolution. The German break reflects the end of the very intensive increase in the ratio between public revenues and GDP initiated in 1928. Whereas up to 1932 this increase was actually provoked by the fall in GDP, later on it went along with the Nazi rearmament plan. On the other hand, the Italian break in 1942 reflects the wartime distortions and the inflationary process that took place after the military partition of the country during the last stages of the war. This time, and despite the increasing public revenues since the mid-1930s, the severe fluctuations of the Italian series and the changing policies of the Mussolini's regime might explain the lack of breaks during the interwar dictatorship. ${ }^{28}$

The increasing public revenues sustained by interwar dictatorships can be also found in Portugal, where the 1925 break fits with the establishment of the Portuguese military dictatorship in 1926 (that ended up with the "Estado Novo" in 1933) and reflect the new militarist policies set up thereafter. By contrast, unlike the interwar autocratic regimes, the Franco's dictatorship in Spain (1939-1975) did not end up with higher public revenues after the Second World War. Despite the initial increase in the fiscal pressure during the war (alongside with increasing military spending), the fiscal system moved back to low levels of taxation, especially compared with the previous democratic period of the Second Republic (1931-1936). The autocratic na-

28. The Italian intervention in the First World War gave place to fiscal increases in 1919 and 1920 (see Figure 2), but the subsequent fiscal reform undertaken by the Ministry of Finance Alberto De'Stefani in 1924/1925 within the new Fascist government returned the fiscal burden to previous levels (along with an outstanding decrease in public expenditures). It was not until the 1930 s that the fascist regime applied substantial fiscal increases to sustain new public works and rearmament policies. See Zamagni (1993). 
ture of the regime in a context of decreasing military expenditures might have prevented to sustain the wartime increases in the fiscal burden. ${ }^{29}$ Actually, the two breaks in 1978 and 1982 fit with the early years of the democratic transitions in Portugal (1974) and Spain (1977), which suggests a positive incidence of democratization on fiscal expansion during the second half of the $20^{\text {th }}$ century.

Finally, both military and non-military factors might explain the long-term growing trend initiated in Sweden in 1937. Even if the country remained neutral in the Second World War, its military expenditures rose significantly in order to prevent any attempts of aggression. In this regard, the 1937 break might partially reflect the temporal special taxes rose during the war, although the change in the trend starts earlier. ${ }^{30}$ Actually, Magnusson (2000) places the foundations of this increasing pattern during the early-1930s, particularly after the Great Depression, when new taxes were raised in order to support municipalities and to compensate for the Great Depression downfall.

29. The increasing military expenditures of that period might be also driven by the violent domestic resistance against the new dictatorial regime. Nevertheless, the Franco's dictatorial regime (1939-1975) participated in the war by sending voluntary troops to fight in the Eastern front with the Nazi forces, while displayed its forces alongside their frontiers in order to prevent an invasion of the peninsula (Cardona, 2008). This mobilization of troops remains critical to understand the military burden evolution (Sabaté, 2013).

30. The reform of the tax system in 1948 (that actually kept the war taxes as permanent revenues) prevented any revenue decrease after the war (Stenkula, Johansson and Du Reitz, 2013). 


\section{THE PERMANENT EFFECTS \\ OF WARFARE ON FISCAL \\ DEVELOPMENT}

In order to further explore the interplay between warfare and fiscal expansion, this section analyses the permanent effects of major wars in the evolution of total and direct tax revenues when controlling for other political and economic factors. To do so, I estimate the following equation:

$$
R_{i t}=\alpha_{o}+\alpha_{1} W A R F A R E_{i t}+\alpha_{2} Z_{i t}+X_{t}+\eta_{i}+\varepsilon_{t}
$$

where $R_{i t}$ is total revenues of the central government (as a share of GDP) in year $t$ and country $i, W A R F A R E_{i t}$ captures the permanent effects of warfare and $Z_{i t}$ stands for a group of control variables. The regressions include country fixed effects, in order to capture those constant country features not included in the model, as well as time fixed effects. As in Dincecco (2009), which in turn relies on Beck and Katz (1995), the analysis is based on an OLS regression model with 'panel corrected' standard errors, along with an AR1 term, in order to control for to the presence of heteroskedasticity, autocorrelation and cross-sectional dependency. ${ }^{31}$ Similarly, I run the following equation for direct tax revenues:

$$
D T_{i t}=\alpha_{o}+\alpha_{1} W A R F A R E_{i t}+\alpha_{2} Z_{i t}+X_{t}+\eta_{i}+\varepsilon_{t}
$$

where $D T_{i t}$ is direct tax revenues of the central government (as a share of GDP) in year $t$ and country $i$, while WARFARE $E_{i t}$ and $Z_{i t}$ stand for the

31. I have also checked for stationarity and cointegration for all the models. According to the results of the Fisher type tests for unit roots in panel datasets we can reject the null of unit roots at 1 per cent of confidence. Moreover, the Kao test for panel cointegration with a lag length selection based on SIC criterion allows rejecting the null of no cointegration at 1 per cent of confidence. 
same group of variables. In both regressions, $W A R F A R E_{i t}$ is a set of variables that take value o before the end of each war and the maximum military burden level of wartime after the conflict. The list of wars included in the analysis is based on two different criteria. Firstly, I consider those wars that implied an increase higher than 100 per cent in the military burden levels achieved in 5 years or less. Secondly, I consider those wars that implied an increase higher than 50 per cent in the military burden levels achieved in 5 years or less as long as they kept the military burden ratio above 5 per cent of GDP. Both measures capture those wars that required a significant budgetary effort (beyond the number of battle deaths that they caused), but the second one avoid those wartimes that provoked high military burden increases but at very low levels. ${ }^{32}$

The group of control variables comprehends both political and economic factors, as well as variables for all wars included in the models. Concerning the latest, these are added in order to control for specific changes during wartimes, and take value o before and after the war and the maximum military burden level during the war. Among the political factors, I include the level of democratization, since representative governments may be more compelled to respond to social demands than autocratic regimes, leading to higher taxes to cover increasing social expenditures. ${ }^{33}$ Additionally, the extension of political participation reduces the income of the median voter (as franchise is progressively extended to poorer people), making parliaments more prone to increase direct taxes on wealthier citizens. All in all, political participation might be related with fiscal expansion. I use the Polity IV index, which estimates the degree of democratization for each country on an annual basis with a scale from -10 to 10 (where the maximum level corresponds to present democratic systems in Western countries).

32. I also applied the condition of a minimum of five years between the wars in order to avoid mixing their effects. When two conflicts are closer in time, I only consider the one with the highest military burden ratio. See Annex B for the list of wars included.

33. Lindert (2004), Espuelas (2012). 
Among economic variables, the analysis incorporates the level of GDP per capita in 1990 Geary-Khamis dollars, in order to control for the potential effects of economic growth on public revenues. An increase in GDP might automatically decrease total revenues and direct tax revenues, measured as a percentage of GDP. However, Wagner's law suggests that economic development is associated to higher government spending, so that the overall effect could be positive. The model also includes an economic openness variable (measured as the ratio between the sum of exports and imports and GDP) in order to control for revenue changes induced by globalization. Higher economic openness might be related to a higher demand for social protection and social expenditure expansion. By contrast, economic openness also increases the international competition among countries and might therefore provoke tax reductions. ${ }^{34}$

Table 4 presents the estimation results of equation (3) and (4). As can be seen in Models 1 and 2, the two world wars show positive and significant results. This points out that the Interwar Revolution's warfare gave place to permanent changes in the public revenue levels. By contrast, most of the remaining wars did not end up with permanently higher revenue levels afterwards, even if new taxes were raised during the outburst of the conflicts. In other words, those wars at the top of the aforementioned inverted 'U-shape' were the only ones that had permanent effects on public revenues, with the only exception of the Second Boer War, which might reflect the higher tax revenue levels sustained in the UK during the first years of the twentieth century. ${ }^{35}$ In this regard, no significant fiscal displacement effect has taken place during the Nuclear Revolution period, which would be consistent with the decreasing side of the inverted 'U-shape', due to the absence of major wars among great powers.

34. Rodrik (1997), Huberman and Lewchuk (2003).

35. This time even the Franco-Prussian War and the American Civil War, which were significant in the structural break analysis, do not appear to be so in the regressions. 
Table 4. Regression results for total and direct tax revenues (1850-1995)

\begin{tabular}{|c|c|c|c|c|}
\hline Dep. variable & $\begin{array}{l}\text { Model1 } \\
\text { Revenues }\end{array}$ & $\begin{array}{l}\text { Model2 } \\
\text { Revenues }\end{array}$ & $\begin{array}{l}\text { Model3 } \\
\text { Direct Tax }\end{array}$ & $\begin{array}{l}\text { Model } 4 \\
\text { Direct Tax }\end{array}$ \\
\hline War variables & $\Delta 100 \%$ & $\Delta 50 \%,>5 \%$ & $\Delta 100 \%$ & $\Delta 50 \%,>5 \%$ \\
\hline Democracy & $\begin{array}{l}4.72 \mathrm{e}-05 \\
(0.000234)\end{array}$ & $\begin{array}{l}-6.54 \mathrm{e}-06 \\
(0.000233)\end{array}$ & $\begin{array}{l}1.36 \mathrm{e}-05 \\
(0.000146)\end{array}$ & $\begin{array}{l}-2.93 \mathrm{e}-05 \\
(0.000142)\end{array}$ \\
\hline Econ. openness & $\begin{array}{l}0.0148 \\
(0.0114)\end{array}$ & $\begin{array}{l}0.0158 \\
(0.0114)\end{array}$ & $\begin{array}{l}-0.0182^{* *} \\
(0.00810)\end{array}$ & $\begin{array}{l}-0.0160^{* *} \\
(0.00798)\end{array}$ \\
\hline GDP pc (log) & $\begin{array}{l}0.0257^{* * *} \\
(0.00702)\end{array}$ & $\begin{array}{l}0.0218^{* * *} \\
(0.00704)\end{array}$ & $\begin{array}{l}0.0179^{* * *} \\
(0.00486)\end{array}$ & $\begin{array}{l}0.0188^{* * *} \\
(0.00484)\end{array}$ \\
\hline WWI & $\begin{array}{l}0.104^{* * *} \\
(0.0187)\end{array}$ & $\begin{array}{l}0.105^{* * *} \\
(0.0195)\end{array}$ & $\begin{array}{l}0.0351^{* * *} \\
(0.0101)\end{array}$ & $\begin{array}{l}0.0297^{* * *} \\
(0.0107)\end{array}$ \\
\hline WWII & $\begin{array}{l}0.0421^{* * *} \\
(0.0160)\end{array}$ & $\begin{array}{l}0.0397^{* *} \\
(0.0162)\end{array}$ & $\begin{array}{l}0.0419^{* * *} \\
(0.00950)\end{array}$ & $\begin{array}{l}0.0384^{* * *} \\
(0.00932)\end{array}$ \\
\hline Crimean War & $\begin{array}{l}-0.208 \\
(0.208)\end{array}$ & $\begin{array}{l}-0.188 \\
(0.208)\end{array}$ & $\begin{array}{l}-0.0367 \\
(0.156)\end{array}$ & $\begin{array}{l}-0.0541 \\
(0.154)\end{array}$ \\
\hline Korean War & $\begin{array}{l}-0.00355 \\
(0.0544)\end{array}$ & $\begin{array}{l}-0.0427 \\
(0.0726)\end{array}$ & $\begin{array}{l}0.123^{* * *} \\
(0.0417)\end{array}$ & $\begin{array}{l}0.168^{* * *} \\
(0.0480)\end{array}$ \\
\hline $\begin{array}{l}\text { Saskatchewan } \\
\text { Rebellion }\end{array}$ & $\begin{array}{l}-0.0688 \\
(1.205)\end{array}$ & & $\begin{array}{l}0.404 \\
(0.655)\end{array}$ & \\
\hline Franco-Prussian War & $\begin{array}{l}0.00719 \\
(0.216)\end{array}$ & $\begin{array}{l}0.0231 \\
(0.221)\end{array}$ & $\begin{array}{l}-0.0776 \\
(0.0888)\end{array}$ & $\begin{array}{l}-0.0758 \\
(0.0863)\end{array}$ \\
\hline Seven Years War & $\begin{array}{l}0.223 \\
(0.258)\end{array}$ & & $\begin{array}{l}-0.00323 \\
(0.229)\end{array}$ & \\
\hline Third Carlist War & $\begin{array}{l}-0.360 \\
(0.244)\end{array}$ & & $\begin{array}{l}-0.0820 \\
(0.128)\end{array}$ & \\
\hline Second Boer War & $\begin{array}{l}0.389^{* *} \\
(0.179)\end{array}$ & $\begin{array}{l}0.357^{* *} \\
(0.178)\end{array}$ & $\begin{array}{l}0.451^{* * *} \\
(0.134)\end{array}$ & $\begin{array}{l}0.354^{* * *} \\
(0.131)\end{array}$ \\
\hline American Civil War & $\begin{array}{l}-0.0271 \\
(0.0699)\end{array}$ & $\begin{array}{l}-0.0328 \\
(0.0716)\end{array}$ & $\begin{array}{l}-0.0196 \\
(0.0605)\end{array}$ & $\begin{array}{l}-0.00640 \\
(0.0602)\end{array}$ \\
\hline $\begin{array}{l}\text { Spanish-American } \\
\text { War }\end{array}$ & $\begin{array}{l}0.0387 \\
(0.616)\end{array}$ & & $\begin{array}{l}0.846^{*} \\
(0.459)\end{array}$ & \\
\hline $\begin{array}{l}\text { Second Spanish- } \\
\text { Moroccan War }\end{array}$ & & $\begin{array}{l}-0.251 \\
(0.207)\end{array}$ & & $\begin{array}{l}-0.220^{* *} \\
(0.0962)\end{array}$ \\
\hline
\end{tabular}


Table 4. (Continuación)

\begin{tabular}{lllll}
\hline \multirow{2}{*}{$\begin{array}{l}\text { Dep. variable } \\
\text { War variables }\end{array}$} & $\begin{array}{l}\text { Model1 } \\
\text { Revenues }\end{array}$ & $\begin{array}{l}\text { Model2 } \\
\text { Revenues }\end{array}$ & $\begin{array}{l}\text { Model3 } \\
\text { Direct Tax }\end{array}$ & $\begin{array}{l}\text { Model4 } \\
\text { Direct Tax }\end{array}$ \\
\cline { 2 - 5 } Constant & $\Delta 100 \%$ & $\Delta 50 \%,>5 \%$ & $\Delta 100 \%$ & $\Delta 50 \%,>5 \%$ \\
\hline Country Fixed Effects & Yes & Yes & Yes & Yes \\
Time Fixed Effects & Yes & Yes & Yes & Yes \\
War variables & Yes & Yes & Yes & Yes \\
Observations & & & & $\left(0.050 .053^{* *}\right.$ \\
R-squared & 1,319 & 1,319 & 1,274 & 1,274 \\
Number of states & 0.577 & 0.555 & 0.547 & 0.541 \\
\hline
\end{tabular}

Notes: For details on the sources, see text and methodological annex. 'Panel corrected' standard errors are used due to the presence of heteroskedasticity, autocorrelation and cross-sectional dependency (standard errors are in brackets). ${ }^{* * *}$ significance at $1 \%,{ }^{* *}$ significance at $5 \%,{ }^{*}$ significance at $10 \%$

Models 3 and 4 show the regression results for direct tax revenues (equation 4). Once again, results are positive and significant for the two World Wars in the two models, which indicates that these wars did not only end up with permanent increases in public revenues but also in direct tax revenues. On the other hand, this time the Second Boer War and the Korean War have had significant effects too. As has been indicated, the former seems to capture the higher tax revenue levels sustained during the first years of the twentieth century in the UK, alongside with the naval race set up in the last stages of the Naval Revolution. This last result (also found out in Models 1 and 2 for total revenues) suggest the Land Warfare and Naval Revolution exerted a positive effect on fiscal expansion in the last stages of the period, when the new costly naval technologies and the increasing international military tension pushed the British military burden up.

On the other hand, the effect of the Korean War might be associated to the recovery of the North-American tax revenue ratios during the out- 
burst of the Asian conflict, which reversed the decreasing trend of the immediate post-Second World War years. According to Rockoff (2012), the Korean War was unique in American experience in the twentieth century as taxes (particularly personal and corporate income taxes) were substantially raised while the Federal Reserve limited the monetization of the federal debt (much used in former wartimes). Even though the income federal rates established during the Second World War were mainly maintained afterwards, the Korean War and the military objectives set up afterwards by the federal authorities (in the context of the Cold War era) brought the ratios again to permanent upper levels.

\subsection{THE ROLE OF POLITICAL REGIMES IN FISCAL PERSISTENCE}

This section further explores the previous results by analysing the role of political regimes in fiscal persistence. Even if it has been a neglected topic in most of the aforementioned literature, political regimes might be relevant in order to better understand the relation between warfare and fiscal expansion. According to Besley and Persson (2009), representative governments should invest more in fiscal capacity than less representative regimes, as governments became more about common interests. It implicitly entails that democracies should favour the positive shifts in public revenues after wartimes compared to autocracies. However, the literature on defence economics has extensively shown that autocratic regimes tend to bear higher military expenditures than democracies..$^{36}$ Therefore, it seems reasonable to expect that those increases in public revenues during both the Land Warfare and Naval Revolutions and the Interwar Revolution that were related to the growth of military spending would have been most strengthened by autocratic regimes. On the contrary, those increases that were most related to non-military purposes should be more strengthened by more representative governments. In order to explore these possibilities, I run the following equation:

36. See, for instance, Goldsmith (2003) and Fordham and Walker (2005). 


$$
R_{i t}=\alpha_{o}+\alpha_{1} W A R F A R E_{i t}^{*} P O L I T I C A L_{i t}+\alpha_{2} Z_{i t}+X_{t}+\eta_{i}+\varepsilon_{t}
$$

where $R_{i t}$ is the level of total public revenues of the central government (measured as a share of GDP) in year $t$ and country $i$, WARFA$R E_{i t}{ }^{*} P O L I T I C A L_{i t}$ is the interaction term between warfare and the degree of democratization, and $Z_{i t}$ is the same set of control variables as in the previous regressions.

Moreover, political regimes might also help to explain the evolution of the structure of fiscal revenues, as it could be expected a positive correlation between democracies and direct taxes. Aidt and Jensen (2009) conclude that the extension of the franchise to poorer citizens favoured the adoption of direct taxes as new voters were who most benefited from income taxation. Moreover, Scheve and Stavage $(2010,2012)$ argue that democracies might need to increase progressive taxes in order to compensate the major battle efforts done by poorer social groups during wartimes. According to them, the societal consensus required to mobilize population for the war effort was easier to maintain if the burden of the war was perceived to be fairly shared among different social groups. Once again, I run the same equation for direct tax revenues in order to explore these features:

$$
D R_{i t}=\alpha_{o}+\alpha_{1} W_{A R F A R E_{i t}^{*}}^{*} P O L I T I C A L_{i t}+\alpha_{2} Z_{i t}+X_{t}+\eta_{i}+\varepsilon_{t}
$$

where $D R_{i t}$ is the level of direct tax revenues of central government (as a share of GDP), and WARFARE ${ }_{i t}{ }^{*}$ POLITICAL $_{i t}$ and $Z_{i t}$ stand for the same group of variables.

Table 5 presents the results of the equations (5) and (6) when the level of democracy is interacted with the two World Wars..$^{37}$ Concerning the total revenues, the interaction term is significant in both wars, being positive for the Second World War and negative for the First World War (Models 1 and 2). This would suggest that, after the First World War, autocratic regimes undertook permanent changes in public revenues

37. The other wars are not interacted with democracy due to the lower degree of political variability among the participant countries. 
above democracies, probably due to the militarist ambitions of the Italian and (particularly) German dictatorships during the 1930s (alongside with their broader public investment plans). Similarly, the establishment of the Portuguese military dictatorship in 1926 increased the ratios of public revenues thereafter. On the other hand, the positive coefficients of the interaction between the Second World War and democracy suggest that democracies favoured permanent changes in public revenues above autocratic regimes, probably due to their higher engagement with Welfare State policies and (especially in the case of the main powers) to the need to invest in innovative and costly military equipment.

Table 5. Regression results for total and direct tax revenues (1850-1995)

\begin{tabular}{|c|c|c|c|c|}
\hline Dep. variable & $\begin{array}{l}\text { Model1 } \\
\text { Revenues }\end{array}$ & $\begin{array}{l}\text { Model2 } \\
\text { Revenues }\end{array}$ & $\begin{array}{l}\text { Model3 } \\
\text { Direct Tax }\end{array}$ & $\begin{array}{l}\text { Model } 4 \\
\text { Direct Tax }\end{array}$ \\
\hline War variables & $\Delta 100 \%$ & $\Delta_{5} \mathrm{O} \%,>5 \%$ & $\Delta 100 \%$ & $\Delta_{5} \mathrm{O} \%,>5 \%$ \\
\hline Democracy & $\begin{array}{l}-0.000125 \\
(0.000217)\end{array}$ & $\begin{array}{l}-0.000121 \\
(0.000214)\end{array}$ & $\begin{array}{l}-9.20 \mathrm{e}-05 \\
(0.000139)\end{array}$ & $\begin{array}{l}-0.000109 \\
(0.000135)\end{array}$ \\
\hline Econ. openness & $\begin{array}{l}0.0169 \\
(0.0115)\end{array}$ & $\begin{array}{l}0.0174 \\
(0.0114)\end{array}$ & $\begin{array}{l}-0.0172^{* *} \\
(0.00822)\end{array}$ & $\begin{array}{l}-0.0152^{*} \\
(0.00811)\end{array}$ \\
\hline GDP pc (log) & $\begin{array}{l}0.0228^{* * *} \\
(0.00694)\end{array}$ & $\begin{array}{l}0.0198^{* * *} \\
(0.00696)\end{array}$ & $\begin{array}{l}0.0164^{* * *} \\
(0.00487)\end{array}$ & $\begin{array}{l}0.0177^{* * * *} \\
(0.00483)\end{array}$ \\
\hline WWI & $\begin{array}{l}0.123^{* * *} \\
(0.0178)\end{array}$ & $\begin{array}{l}0.125^{* * *} \\
(0.0186)\end{array}$ & $\begin{array}{l}0.0419^{* * *} \\
(0.0107)\end{array}$ & $\begin{array}{l}0.0366^{* * *} \\
(0.0113)\end{array}$ \\
\hline WWI*democracy & $\begin{array}{l}-0.00295^{* * *} \\
(0.000907)\end{array}$ & $\begin{array}{l}-0.00293^{* * *} \\
(0.000909)\end{array}$ & $\begin{array}{l}-0.00113^{*} \\
(0.000672)\end{array}$ & $\begin{array}{l}-0.000950 \\
(0.000655)\end{array}$ \\
\hline WWII & $\begin{array}{l}-0.209^{* * *} \\
(0.0492)\end{array}$ & $\begin{array}{l}-0.209^{* * *} \\
(0.0497)\end{array}$ & $\begin{array}{l}-0.0326 \\
(0.0254)\end{array}$ & $\begin{array}{l}-0.0226 \\
(0.0253)\end{array}$ \\
\hline WWII*democracy & $\begin{array}{l}0.0246^{* * *} \\
(0.00460)\end{array}$ & $\begin{array}{l}0.0243^{* * *} \\
(0.00467)\end{array}$ & $\begin{array}{l}0.00743^{* * *} \\
(0.00240)\end{array}$ & $\begin{array}{l}0.00608^{* * *} \\
(0.00237)\end{array}$ \\
\hline Crimean War & $\begin{array}{l}-0.207 \\
(0.202)\end{array}$ & $\begin{array}{l}-0.188 \\
(0.202)\end{array}$ & $\begin{array}{l}-0.0343 \\
(0.155)\end{array}$ & $\begin{array}{l}-0.0520 \\
(0.153)\end{array}$ \\
\hline Korean War & $\begin{array}{l}-0.0166 \\
(0.0534)\end{array}$ & $\begin{array}{l}-0.0558 \\
(0.0702)\end{array}$ & $\begin{array}{l}0.115^{* * *} \\
(0.0414)\end{array}$ & $\begin{array}{l}0.160^{* * *} \\
(0.0477)\end{array}$ \\
\hline $\begin{array}{l}\text { Saskatchewan } \\
\text { Rebellion }\end{array}$ & $\begin{array}{l}-0.0442 \\
(1.186)\end{array}$ & & $\begin{array}{l}0.423 \\
(0.647)\end{array}$ & \\
\hline
\end{tabular}


Table 5. (Continuación)

\begin{tabular}{|c|c|c|c|c|}
\hline Dep. variable & $\begin{array}{l}\text { Model1 } \\
\text { Revenues }\end{array}$ & $\begin{array}{l}\text { Model2 } \\
\text { Revenues }\end{array}$ & $\begin{array}{l}\text { Model3 } \\
\text { Direct Tax }\end{array}$ & $\begin{array}{l}\text { Model } 4 \\
\text { Direct Tax }\end{array}$ \\
\hline War variables & $\Delta 100 \%$ & $\Delta 50 \%,>5 \%$ & $\Delta 100 \%$ & $\Delta 50 \%,>5 \%$ \\
\hline \multirow[t]{2}{*}{$\begin{array}{l}\text { Franco-Prussian } \\
\text { War }\end{array}$} & 0.0358 & 0.0417 & -0.0643 & -0.0695 \\
\hline & $(0.208)$ & $(0.212)$ & (o.0892) & $(0.0867)$ \\
\hline Seven Years War & $\begin{array}{l}0.211 \\
(0.265)\end{array}$ & & $\begin{array}{l}-0.0110 \\
(0.229)\end{array}$ & \\
\hline Third Carlist War & $\begin{array}{l}-0.276 \\
(0.234)\end{array}$ & & $\begin{array}{l}-0.0510 \\
(0.120)\end{array}$ & \\
\hline Second Boer War & $\begin{array}{l}0.418^{* *} \\
(0.176)\end{array}$ & $\begin{array}{l}0.395^{* *} \\
(0.175)\end{array}$ & $\begin{array}{l}0.456^{* * *} \\
(0.134)\end{array}$ & $\begin{array}{l}0.358^{* * *} \\
(0.132)\end{array}$ \\
\hline \multirow[t]{2}{*}{$\begin{array}{l}\text { American Civil } \\
\text { War }\end{array}$} & -0.0256 & -0.0299 & -0.0184 & -0.00447 \\
\hline & $(0.0690)$ & $(0.0705)$ & (0.0602) & (0.0598) \\
\hline \multirow[t]{2}{*}{$\begin{array}{l}\text { Spanish-American } \\
\text { War }\end{array}$} & 0.0507 & & $0.858^{*}$ & \\
\hline & $(0.595)$ & & $(0.453)$ & \\
\hline \multirow[t]{2}{*}{$\begin{array}{l}\text { Second Spanish- } \\
\text { Moroccan War }\end{array}$} & & -0.115 & & $-0.169^{*}$ \\
\hline & & $(0.200)$ & & $(0.0932)$ \\
\hline Constant & $\begin{array}{l}-0.0628 \\
(0.0723)\end{array}$ & $\begin{array}{l}-0.0283 \\
(0.0731)\end{array}$ & $\begin{array}{l}-0.105^{* *} \\
(0.0504)\end{array}$ & $\begin{array}{l}-0.111^{* *} \\
(0.0505)\end{array}$ \\
\hline $\begin{array}{l}\text { Country Fixed } \\
\text { Effects }\end{array}$ & Yes & Yes & Yes & Yes \\
\hline Time Fixed Effects & Yes & Yes & Yes & Yes \\
\hline War variables & Yes & Yes & Yes & Yes \\
\hline Observations & 1,319 & 1,319 & 1,274 & 1,274 \\
\hline R-squared & 0.598 & 0.579 & 0.551 & 0.541 \\
\hline Number of states & 10 & 10 & 10 & 10 \\
\hline
\end{tabular}

Notes: For details on the sources, see text and methodological annex. 'Panel corrected' standard errors are used due to the presence of heteroskedasticity, autocorrelation and cross-sectional dependency (standard errors are in brackets). ${ }^{* * *}$ significance at $1 \%,{ }^{* *}$ significance at $5 \%$, ${ }^{*}$ significance at $10 \%$ 
Models 3 and 4 show the regression results for direct tax revenues (equation 6). The coefficient of the interaction term between democracy and the Second World War is also positive and significant. Therefore, as could be expected, democracies appear to have been more engaged in progressive taxation than autocratic regimes after 1945. By contrast, the coefficient of the interaction between democracy and the First World War is barely significant and negative in model 5 and becomes insignificant in Model 6, suggesting that the higher fiscal effort done by dictatorships after 1918 was not equally corresponded by direct taxation.

\subsection{THE ROLE OF CIVILIAN AND MILITARY \\ EXPENDITURES IN FISCAL PERSISTENCE}

This section aims to complement the previous results by analysing if the observed (permanent) fiscal changes were driven by the increase in either military or civil public expenditures. In order to do so, I run the following equation:

$$
R_{i t}=\alpha_{o}+\alpha_{1} W_{A R F A R E_{i t}}{ }^{*} C I V I L M I L E X_{i t}+\alpha_{2} Z_{i t}+X_{t}+\eta_{i}+\varepsilon_{t}
$$

where $R_{i t}$ is the level of total public revenues of the central government (measured as a share of GDP) in year $t$ and country $i$, WARFA$R E_{i t}{ }^{*} C I V I L M I L E X_{i t}$ is the interaction term between warfare and the ratio between civil and military expenditure, and $Z_{i t}$ is the same set of control variables as in the previous regressions. A positive coefficient of the interaction variable would suggest that higher civil expenditure was positively associated with higher public revenues after the war (and was therefore presumably driving the revenue increase), while a negative one would indicate that the displacement effect was more associated with a higher military expenditure. The interaction term has been applied to those wars that had positive effects in the former regressions and that provide enough variability among countries. Once again, I run the same equation for direct tax revenues: 


$$
D R_{i t}=\alpha_{o}+\alpha_{1} W_{A R F A R E_{i t}{ }^{*} C I V I L M I L E X} X_{i t}+\alpha_{2} Z_{i t}+X_{t}+\eta_{i}+\varepsilon_{t}
$$

where $D R_{i t}$ is the level of direct tax revenues of central government (as a share of GDP), and WARFARE $E_{i t}{ }^{*} C I V I L M I L E X_{i t}$ and $Z_{i t}$ stand for the same group of variables. ${ }^{38}$

Table 6 presents the results for both total and direct tax revenues. Whereas the coefficient of the interaction term is not significant in the case of the First World War (which indicates that the prominence of civil expenditure was not specifically strengthening the permanent increase in public revenues), in the case of the Second World War it is positive and significant in both Models 1 and 2. In other words, the Second World War gave place to permanent increases in public revenues in those cases that the ratio between civil and military expenditure was above the mean. These results mainly fit with the insights presented in previous section: democracies strengthened the effects of wartimes over autocracies when civilian expenditure was more relevant to understand persistence.

Table 6. Regression results for total and direct tax revenues (1850-1995)

\begin{tabular}{|c|c|c|c|c|}
\hline Dep. variable & $\begin{array}{l}\text { Model1 } \\
\text { Revenues }\end{array}$ & $\begin{array}{l}\text { Model2 } \\
\text { Revenues }\end{array}$ & $\begin{array}{l}\text { Model3 } \\
\text { Direct Tax }\end{array}$ & $\begin{array}{l}\text { Model } 4 \\
\text { Direct Tax }\end{array}$ \\
\hline War variables & $\Delta 100 \%$ & $\Delta 50 \%,>5 \%$ & $\Delta 100 \%$ & $\Delta_{50} \%,>5 \%$ \\
\hline Democracy & $\begin{array}{l}-0.000136 \\
(0.000238)\end{array}$ & $\begin{array}{l}-0.000201 \\
(0.000235)\end{array}$ & $\begin{array}{l}-4.63 \mathrm{e}-05 \\
(0.000154)\end{array}$ & $\begin{array}{l}-0.000109 \\
(0.000151)\end{array}$ \\
\hline Econ. openness & $\begin{array}{l}0.0151 \\
(0.0135)\end{array}$ & $\begin{array}{l}0.0165 \\
(0.0134)\end{array}$ & $\begin{array}{l}-0.0198^{* *} \\
(0.00850)\end{array}$ & $\begin{array}{l}-0.0208^{* *} \\
(0.00850)\end{array}$ \\
\hline GDP pc (log) & $\begin{array}{l}0.0251^{* * *} \\
(0.00814)\end{array}$ & $\begin{array}{l}0.0214^{* * *} \\
(0.00819)\end{array}$ & $\begin{array}{l}0.0194^{* * *} \\
(0.00539)\end{array}$ & $\begin{array}{l}0.0187^{* * *} \\
(0.00546)\end{array}$ \\
\hline $\begin{array}{l}\text { Civil/military expen- } \\
\text { diture }\end{array}$ & 0.000165 & 0.000162 & $-4.57 \mathrm{e}-05$ & -1.46 \\
\hline & (0.000161) & (0.000144) & $(9.63 \mathrm{e}-05)$ & $(8.73 \mathrm{e}-05)$ \\
\hline WWI & $\begin{array}{l}0.112^{* * *} \\
(0.0199)\end{array}$ & $\begin{array}{l}0.109^{* * *} \\
(0.0212)\end{array}$ & $\begin{array}{l}0.0338^{* * *} \\
(0.0115)\end{array}$ & $\begin{array}{l}0.0261^{* *} \\
(0.0121)\end{array}$ \\
\hline
\end{tabular}

38. German civil expenditure includes the payment of debt interests, because it has not been possible to compile enough disaggregated data. 
Table 6. (Continuación)

\begin{tabular}{|c|c|c|c|c|}
\hline Dep. variable & $\begin{array}{l}\text { Model1 } \\
\text { Revenues }\end{array}$ & $\begin{array}{l}\text { Model2 } \\
\text { Revenues }\end{array}$ & $\begin{array}{l}\text { Model3 } \\
\text { Direct Tax }\end{array}$ & $\begin{array}{l}\text { Model4 } \\
\text { Direct Tax }\end{array}$ \\
\hline War variables & $\Delta 100 \%$ & $\Delta_{50} \%,>5 \%$ & $\Delta 100 \%$ & $\Delta_{50} \%,>5 \%$ \\
\hline WWI* Civilexp & $\begin{array}{l}-0.00161 \\
(0.00205)\end{array}$ & $\begin{array}{l}-0.00117 \\
(0.00207)\end{array}$ & $\begin{array}{l}-0.000232 \\
(0.00119)\end{array}$ & $\begin{array}{l}-0.000373 \\
(0.00120)\end{array}$ \\
\hline WWII & $\begin{array}{l}0.0214 \\
(0.0177)\end{array}$ & $\begin{array}{l}0.0186 \\
(0.0181)\end{array}$ & $\begin{array}{l}0.0343^{* * *} \\
(0.0127)\end{array}$ & $\begin{array}{l}0.0365^{* * *} \\
(0.0124)\end{array}$ \\
\hline WWII* Civilexp & $\begin{array}{l}0.00873^{* * *} \\
(0.00247)\end{array}$ & $\begin{array}{l}0.00851^{* * *} \\
(0.00247)\end{array}$ & $\begin{array}{l}0.00117 \\
(0.00154)\end{array}$ & $\begin{array}{l}0.000970 \\
(0.00155)\end{array}$ \\
\hline Korean War & $\begin{array}{l}0.0462 \\
(0.0726)\end{array}$ & $\begin{array}{l}0.0363 \\
(0.0723)\end{array}$ & $\begin{array}{l}0.113^{* *} \\
(0.0548)\end{array}$ & $\begin{array}{l}0.127^{* *} \\
(0.0531)\end{array}$ \\
\hline Crimean War & $\begin{array}{l}-0.230 \\
(0.221)\end{array}$ & $\begin{array}{l}-0.206 \\
(0.224)\end{array}$ & $\begin{array}{l}-0.0292 \\
(0.159)\end{array}$ & $\begin{array}{l}-0.0436 \\
(0.157)\end{array}$ \\
\hline $\begin{array}{l}\text { Saskatchewan Rebe- } \\
\text { llion }\end{array}$ & $\begin{array}{l}0.246 \\
(1.480)\end{array}$ & & $\begin{array}{l}0.361 \\
(0.866)\end{array}$ & \\
\hline Franco-Prussian War & $\begin{array}{l}0.0293 \\
(0.228)\end{array}$ & $\begin{array}{l}0.0483 \\
(0.234)\end{array}$ & $\begin{array}{l}-0.0615 \\
(0.0962)\end{array}$ & $\begin{array}{l}-0.0670 \\
(0.0901)\end{array}$ \\
\hline Seven Years War & $\begin{array}{l}0.193 \\
(0.284)\end{array}$ & & $\begin{array}{l}0.00167 \\
(0.176)\end{array}$ & \\
\hline Third Carlist War & $\begin{array}{l}-0.352 \\
(0.220)\end{array}$ & & $\begin{array}{l}-0.0978 \\
(0.146)\end{array}$ & \\
\hline Second Boer War & $\begin{array}{l}0.533^{* * *} \\
(0.200)\end{array}$ & $\begin{array}{l}0.479^{* *} \\
(0.204)\end{array}$ & $\begin{array}{l}0.457^{* * *} \\
(0.128)\end{array}$ & $\begin{array}{l}0.445^{* * *} \\
(0.126)\end{array}$ \\
\hline American Civil War & $\begin{array}{l}-0.0389 \\
(0.0963)\end{array}$ & $\begin{array}{l}-0.0439 \\
(0.0997)\end{array}$ & $\begin{array}{l}-0.0184 \\
(0.0796)\end{array}$ & $\begin{array}{l}-0.00587 \\
(0.0793)\end{array}$ \\
\hline $\begin{array}{l}\text { Spanish-American } \\
\text { War }\end{array}$ & $\begin{array}{l}0.110 \\
(0.813)\end{array}$ & & $\begin{array}{l}0.846 \\
(0.619)\end{array}$ & \\
\hline $\begin{array}{l}\text { Second Spanish-Mo- } \\
\text { roccan War }\end{array}$ & & $\begin{array}{l}-0.301^{*} \\
(0.183)\end{array}$ & & $\begin{array}{l}-0.285^{* *} \\
(0.111)\end{array}$ \\
\hline Constant & $\begin{array}{l}-0.100 \\
(0.0848)\end{array}$ & $\begin{array}{l}-0.0571 \\
(0.0860)\end{array}$ & $\begin{array}{l}-0.123^{* *} \\
(0.0562)\end{array}$ & $\begin{array}{l}-0.105^{*} \\
(0.0570)\end{array}$ \\
\hline Country Fixed Effects & Yes & Yes & Yes & Yes \\
\hline Time Fixed Effects & Yes & Yes & Yes & Yes \\
\hline
\end{tabular}


Table 6. (Continuación)

\begin{tabular}{lllll}
\hline \multirow{2}{*}{$\begin{array}{l}\text { Dep. variable } \\
\text { War variables }\end{array}$} & $\begin{array}{l}\text { Model1 } \\
\text { Revenues }\end{array}$ & $\begin{array}{l}\text { Model2 } \\
\text { Revenues }\end{array}$ & $\begin{array}{l}\text { Model3 } \\
\text { Direct Tax }\end{array}$ & $\begin{array}{l}\text { Model4 } \\
\text { Direct Tax }\end{array}$ \\
\cline { 2 - 5 } War variables & Yes & $\Delta 50 \%,>5 \%$ & $\Delta 100 \%$ & $\Delta 50 \%,>5 \%$ \\
Observations & 1,193 & 1,193 & Yes & Yes \\
R-squared & 0.642 & 0.620 & 0.549 & 0.560 \\
Number of states & 10 & 10 & 10 & 10 \\
\hline
\end{tabular}

Notes: For details on the sources, see text and methodological annex. 'Panel corrected' standard errors are used due to the presence of heteroskedasticity, autocorrelation and cross-sectional dependency (standard errors are in brackets). ${ }^{* * *}$ significance at $1 \%,{ }^{* *}$ significance at $5 \%,{ }^{*}$ significance at $10 \%$

Models 3 and 4 present the results for direct tax revenues. In this case neither the First nor the Second World Wars seem to have had significant effects (even though the signs of the coefficients remain the same than in total revenues). Concerning the Second World War, these results suggest that those countries that ended up with permanent fiscal increases due to their higher civilian expenditures were forced to increase indirect taxes in order to finance it. It additionally implies that those democratic regimes that strengthened the permanent increases on direct tax revenues after the Second World War were not necessarily doing so due to the higher prominence of civilian expenditures (as the case of the US exemplifies, in which direct taxes increased in a context of higher prominence of military burden). 


\section{CONCLUSIONS}

Warfare has been considered a key factor for the expansion of fiscal capacity during early and late modern periods. This paper has explored the interplay between warfare, military pressure and fiscal expansion by analysing the permanent effects of late-modern warfare on a sample of major and secondary powers in the light of the historical 'Revolutions in Military Affairs'. The results point out that the interplay between warfare and fiscal expansion has followed an inverted 'U-shape' pattern, in which the Interwar Revolution warfare has been related to major permanent increases in total and direct taxes revenues of central governments. On the other hand, the Nuclear Revolution allowed an impressive increase in destructive power with lower costs, which has made major wars more unlikely and has prevented new war-related displacements effects on fiscal systems. This result suggests that the interplay between warfare and fiscal development cannot be categorized with a permanent general law but needs to be analysed as a particular historical phenomenon.

Moreover, the paper has explored the role of political regimes in the former war-lead narrative. In this regard, the positive impact of the First World War on public revenues was stronger under autocratic regimes, while the opposite held after the Second World War. The analysis on the composition of expenditures suggests that, during the Interwar period, autocracies pushed revenues up due to their militaristic policies, whereas revenue increases under democracies after the Second World War were driven by their major engagement with welfare policies (while they kept investing in the preparation for further major conventional wars). On the other hand, democracies after the Second World War and the Korean War not only increased their total public revenues but also their direct taxes, which reflect their major engagement with fiscal progressivity. These results entail that the impact of wartimes in fiscal expansion is not necessarily progressive, as autocratic regimes and militaristic policies might be part of this phenomenon. 


\section{REFERENCES}

Abelshauser, Werner (1998): "Germany: guns, butter, and economic miracles", in Harrison, Mark (ed.) The economics of World War II. Six great powers in international comparison, Cambridge: Cambridge University Press, pg.122-169

Aidt, Toke S.; Jensen, Peter S. (2009): "The taxman tools up: An event history study of the introduction of the personal income tax, 1815-1938", Journal of Public Economics, 93 (1): 160-175

- Andic, S; Veverka, J. (1964): "The Growth of Government Expenditure in Germany since the Unification", Finanzarchiv, XXIII

- Baffigi, Alberto (2011): "Italian National Accounts 1861-2011. A project of Banca d'Italia, Istat, University of Rome "Tor Vergata”", Economic History Working Papers, Banca d'Italia, n. 18

- Bailey, Jonathan B.A. (2001): "The First World War and the birth of modern warfare", in Knox, MacGregor; Murray, Williamson (eds.) The dynamics of military revolution, 1300-2050, New York: Cambridge University Press, pg. 132-153

Banks, A. S. (1976): Cross-National Time Series, 1815-1973, vol. 2001, Ann Arbor, MI: Inter-University Consortium for Political and Social Research (ICPSR).

- Beck, Nathaniel; Jonathan Katz. (1995): "What to Do (and Not to Do) with Time Series Cross-Section Data", American Political Science Review, 89 (3): 634-647

- Besley, Timothy; Persson, Torsten (2009): "The Origins of State Capacity: Property Rights, Taxation, and Politics", American Economic Review, 99 (4): 1218-1244

- Bird, Richard M. (1983): "Section H: Government Finance", in Historical Statistics of Canada, Social Science Federation of Canada and Statistics Canada, Chapter 8

Black, Jeremy (2006): The age of total war, 1860-1945, Westport: Praeger Security International

- Bonney, Richard; Ormrod, W. Mark (1999): “Crises, Revolutions and Self-Sustained Growth: Towards a conceptual Model of Change 
in Fiscal History”, in Ormrod, W.M.; Bonney, M; Bonney R. (eds.) Crises, Revolutions and Self-Sustained Growth, Stamford CT: Shaun Tyas, pg. 1-20

- Broadberry, Stephen; Harrison, Mark (2005): “The economics of World War I: an overview", in Broadberry, Stephen; Harrison, Mark (eds.) The economics of World War I, Cambridge: Cambridge University Press, pg. 3-40.

- Broadberry, Stephen; Howlett, Peter (1998): “The United Kingdom: 'Victory at all costs", in Harrison, Mark (ed.) The economics of World War II. Six great powers in international comparison, Cambridge: Cambridge University Press, pg.43-80.

- Brzoska, Michael (1995): "World Military Expenditures. A Handbook of Defence Economics”, in Hartley, K. y Sandler, T (eds.) Handbook of Defence Economics, Volume I, Elsvier Science B.V.

- Cardona, Gabriel (2008): El Poder militar en el franquismo: las bayonetas de papel, Barcelona, Flor del Viento

- Carter, Susan B. (2006): Historical Statistics of the United States. Earliest times to the present, New York: Cambridge University Press, Vol. 5

Comín, Francisco; Díaz Fuentes, Daniel (2005): "Sector público administrativo y estado del bienestar”, in Carreras, Albert; Xavier Tafunell (coords.): Estadísticas históricas de España. Siglos XIX y $X X$. Bilbao: Fundación BBVA, pg. 873-964.

Crozier, Robert B. (1983): "Section F: Gross National Product, the Capital Stock and Productivity”, in Historical Statistics of Canada, Social Science Federation of Canada and Statistics Canada, Chapter 6

Dincecco, Mark (2009): "Fiscal centralization, limited government and public revenues in Europe, 1650-1913”, Journal of Economic History, 69 (1): 48-103

- Dincecco, Mark; Federico, Giovanni; Vindigni, Andrea (2011): "Warfare, taxation and political change: evidence from the Italian Risorgimento", Journal of Economic History, 71 (4): 887-914

Dincecco, Mark; Prado, Mauricio (2012): "Warfare, fiscal capacity, and performance”, Journal of Economic Growth, 17 (3): 171-203 
Eloranta, Jari (2007): "From the Great Illusion to the Great War: Military Spending

- Behaviour of the Great Powers, 1870-1913", European Review of Economic History, 11:2, 255-283

- Espuelas, Sergio (2012): "Are dictatorships less redistributive? A comparative analysis of social spending in Europe (1950-1980)", European Review of Economic History, 16:2, 211-232

- Espuelas, Sergio (2014): "The inequality Trap. A Comparative Analysis of Social Spending Between 1880 and 1933", Economic History Review (forthcoming)

- Fontvieille, Louis (1976): Evolution et croissance de l'Etat Français: 1815-1969, Paris: Institut de sciences mathématiques etéconomiques appliqués

- Fordham, Benjamin O.; Walker, Thomas C. (2005): "Kantian Liberalism, Regime Type, and Military Resource Allocation: Do Democracies Spend Less?”, International Studies Quarterly, 49:1, 141-157

- Fregert, Klas; Gustafsson, Roger (2007): "Fiscal statistics for Sweden, 1719-2003”, Research in Economic History, 25: 169-223

- Goldsmith, Benjamin E. (2007): "Defense Effort and Institutional Theories of Democratic Peace and Victory Why Try Harder?", Security Studies, 16:2, 189-222

- Gongora, Thierry; Riekhoff, Harald Von (2000): "Introduction: Sizing up the Revolution in Military Affair", in Gongora, Thierry; Riekhoff, Harald Von (eds.) Toward a Revolution in Military Affairs? Defense and Security at the Dawn of the Twenty-First Centurty, Westport: Greenwood Press, pg. 1-20

- Grimsley, Mark (2001): "Surviving military revolution: The U.S. Civil War", in Knox, MacGregor; Murray, Williamson (eds.) The dynamics of military revolution, 1300-2050, New York: Cambridge University Press, pg. 74-91

- Grytten, O.H. (2004). "The gross domestic product for Norway 1830-2003", in Eitrheim, Ø.; Klovland, J. T.; Zvigstad, J. F. (eds.): Historical Monetary Statistics for Norway 1819-2003, Norges Bank Occasional Papers no. 35, Oslo, pg. 241-288, 
- Herwig, Hogler H. (2001): "The battlefleet revolution, 1885-1914", in Knox, MacGregor; Murray, Williamson (eds.) The dynamics of military revolution, 1300-2050, New York: Cambridge University Press, pg. 114-131

- Hoffman, Philip T. (2012): "Why Was It Europeans Who Conquered the World?”, The Journal of Economic History, 72 (3): 601-633

- Hoffman, Philip T.; Rosenthal, Jean-Laurent (1997): "The Political Economy of Warfare and Taxation in Early Modern Europe: Historical Lessons for Economic Development”, in Drobak, John N.; Nye, John V. C. (eds.) The Frontiers of the New Institutional Economics, San Diego: Harcourt Brace, Academic Press

- Huberman, Michael; Lewchuk, Wayne (2003): "European economic integration and the labour compact, 1850-1913”, European Review of Economic History, 7 (1): 3-41.

- Jaggers, Keith (1992): "War and the Three Faces of Power. War Making and State Making in Europe and the Americas", Comparative Political Studies, 25 (1): 26-62

- Jones, Matthew T.; Obstfeld, Maurice (2001): "Saving, Investment, and Gold: A Reassessment of Historical Current Account Data," in Calvo, Guillermo A., Dornbusch, Rudi; Obstfeld, Maurice (eds.) Money, Capital Mobility, and Trade: Essays in Honor of Robert Mundell, Cambridge, MA: MIT Press

- Knox, MacGregor (2001): "Mass politics and nationalism as military revolution: The French Revolution and after", in Knox, MacGregor; Murray, Williamson (eds.) The dynamics of military revolution, 1300-2050, New York: Cambridge University Press, pg. 57-73

Krepinevich, Andrew (1994): "From Calvalry to Computers. The Pattern of Military Revolutions", The National Interest, 37: 30-42

- Krüger, Kersten (1987): "Public finance and modernisation: the change from the domain state to tax state in Hesse in the sixteenth and seventeenth centuries", in Will, P.C. (ed.) Wealth and Taxation in Central Europe: the History and Sociology of Public Finance, New York: Berg Publishers Limited, pg. 49-62

Lindert, Peter H. (2004): Growing public social spending and eco- 
nomic growth since the eighteenth century (Volum I and II), Cambridge, Cambridge University Press

Magnusson, Lars (2000): An Economic History of Sweden, New York: Routledge Explorations in Economic History

Mitchell, Brian R. (1990): British Historical Statistics, Cambridge: Cambridge University Press

Mitchell, Brian R. (2003): International historical statistics: Europe, 1750-200o, New York, Palgrave Macmillan, $5^{\text {th }}$ edition

Mitchell, Brian R. (2007): International historical statistics: the Americas, 1750-2005, New York: Palgrave Macmillan, 6th edition

Murray, Williamson; Knox, MacGregor (2001): "Thinking about revolutions in warfare", in Knox, MacGregor; Murray, Williamson (eds.) The dynamics of military revolution, 1300-2050, New York: Cambridge University Press, pg. 1-14

- Obinger, Herbert; Petersen, Klaus (2014): "Mass warfare and the welfare: State causal

- mechanisms and effects", ZeS-Arbeitspapier, No. 02/2014

- O'Brien, Patrick K. (2011): "The nature and historical evolution of an exceptional fiscal state and its possible significant for the precocious commercialization and industrialization of the British Economy from Cromwell to Nelson", Economic History Review, 64 (2): 408-446

- Onorato, Massimiliano G.; Scheve, Kenneth; Stasavage, David (2014): "Technology and the Era of Mass Army", The Journal of Economic History, 74 (2): 449-481

- Parker, Geoffrey (2010): "Introducción. La práctica occidental de la guerra”, in Parker, Geoffrey (ed.) Historia de la guerra, Madrid: Ediciones Akal, pg. 7-20

- Peacock, Alan T.; Wiseman, Jack (1961): The growth of public expenditures in the United Kingdom, Princeton, N.J.: Princeton University Press

Petzina, Von Dietmar; Abelshauser, Werner; Faust, Anselm (1978): Sozialgeschichtliches Arbeitsbuch III. Materialien zur Statistik des Deutschen Reiches 1914-1945, Munich: Verlag C.H. Beck München Prados de la Escosura, Leandro (2003): El progreso de España, 1850-200o, Madrid: Fundación BBVA 
- Ragioneria generale dello Stato (2011): La spesa dello stato dall'unità d'Italia. Anni 1862-2009, Ministerio dell'Economia e delle Finanze

- Rasler, Karen A.; Thompson, William R. (1985): "War Making and State Making: Governmental Expenditures, Tax Revenues, and Global Wars", The American Political Science Review, 79 (2): 491-507

- Ritschl, Albrecht (2005): "The pity of peace: Germany's economy at war, 1914-1918 and beyond", in Broadberry, Stephen; Harrison, Mark (eds.) The economics of World War I, Cambridge: Cambridge University Press, pg. 41-76

- Rockoff, Hugh (2012): America's Economic Way of War. War and the US Economy from the Spanish-American War to the Persian Gulf War, New York: Cambridge University Press

- Rodrik, Dani (1997): Has globalization gone too far?, Washington: Institute for International Economy

- Rogers, Clifford (2000): "Military Revolutions and Revolutions in Military Affairs: a Historian's Perspective”, in Gongora, Thierry; Riekhoff, Harald Von (eds.) Toward a Revolution in Military Affairs? Defense and Security at the Dawn of the Twenty-First Centurty, Westport: Greenwood Press, pg. 21-36

- Sabaté, Oriol (2013): "New quantitative estimates on long-term military spending in Spain (1850-2009)”, ICIP Working Papers, 2013/o6 Scheve, Kenneth; Stasavage, David (2010): "The conscription of wealth: Mass warfare and the demand for progressive taxation", International Organization, 64 (4): 529-561

- Scheve, Kenneth; Stasavage, David (2012): "Democracy, war, and wealth: Evidence of two centuries of inheritance taxation", American Political Science Review, 106 (1): 81-102

Schön, Lennart; Krantz, Olle (2012): "Swedish Historical National Accounts 1560-2010", Lund Papers in Economic History 123, Lund University.

Schumpeter, Joseph A. (1918): “The Crisis of Tax State”, International Economic Papers, 4 [1954]: 5-38

Showalter, Dennis E. (2001): "The Prusso-German RMA, 18401871", in Knox, MacGregor; Murray, Williamson (eds.) The dynam- 
ics of military revolution, 1300-2050, New York: Cambridge University Press, pg. 92-113

Smits, Jan-Pieter.; Woltjer, Pieter; Ma, Debin (2009): "A Dataset on Comparative Historical National Accounts, ca. 1870-1950: A Time-Series Perspective", Groningen Growth and Development Centre Research Memorandum GD-107, Groningen: University of Groningen

- Statistisk Centralbyra (1926): Statistiske Oversikter, 1948. Utgitt Av det Statistike Centralbyra, Olso: I Kommisjon Hos H. Aschehoug \& Co.

- Statistisk Sentralbyra (1949): Norges Offisielle Statistikk. X. 178. Statistiske Oversikter, 1948, Olso: Statistisk Sentralbyra

- Statistisk Sentralbyra (1959): Norges Offisielle Statistikk. XI. 330. Statistiske Oversikter, 1958, Olso: Statistisk Sentralbyra

- Stenkula, Mikael; Johansson, Dan; Du Reitz, Gunnar (2013): "Marginal taxation on labour income in Sweden from 1862 to 2010", Scandinavian Economic History Review, DOI:10.1080/03585522 .2013 .836985

- Tena, Antonio (2005): "Sector exterior", in Carreras, Albert; Xavier Tafunell (coords.): Estadísticas históricas de España. Siglos XIX y $X X$. Bilbao: Fundación BBVA, pg. 572-643.

Tilly, Charles (1990): Coercion, capital and European states, $A D$ 990-1990, Cambridge: Basil Blackwell

- Valério, Nuno (Ed.) (2001): Portuguese Historical Statistics, Lisbon: Instituto Nacional de Estatística (2 vols.)

- Yun-Casalilla, Bartolomé (2012): "Introduction: the rise of the fiscal state in Eurasia from a global, comparative and transational perspective”, in Yun-Casalilla, Bartolomé; O'Brien, Patrick K.; with Comín Comín, Francisco (eds.) The Rise of Fiscal States. A Global History, 1500-1914, New York: Cambridge University Press, pg. 1-38 Zamagni, Vera (1998): "Italy: how to lose the war and win the peace", in Harrison, Mark (ed.) The economics of World War II. Six great powers in international comparison, Cambridge: Cambridge University Press, pg.177-223. 



\section{ANNEX A. DATA}

\section{Canada}

Nominal military expenditures (ME) from Bird (1983) for 1867-1948 and from the NATO dataset for 1949-1995. Gross Domestic Product (GDP) from Jones and Obstfeld (2001) for 1870-1925, from Crozier (1983) for 1926-1976 and from Mitchell (2007) for 1977-1995. Central Government Revenues (CGR) and Direct Tax Revenues from Central Government (DT) from Mitchell (2007), and Civil Expenditures (CIVILEX) from Bird (1983) and Mitchell (2007). Exports and Imports data from Mitchell (2007).

\section{France}

ME from Fontvieille (1976) for 1850-1939 and from the NATO dataset for 1949-1995. Nominal GDP from Smits, Woltjer and Ma (2009) for 1850-1913 and 1920-1938; from Jones and Obstfeld (2001) for 19141919 and 1939; and from the National Institute of Statistics and Economic Studies (INSEE) dataset for 1949-1995. CGR and DT from Mitchell (2003) for 1850-1977 and from INSEE for 1978-1995. CIVILEX from Fontvieille (1976) and Mitchell (2003) for 1850-1977 and from Mitchell (2003) and the National Institute of Statistics and Economic Studies (INSEE) dataset for 1949-1995. Exports and Imports data from Mitchell (2003).

\section{Germany}

ME from Andic and Veverka (1963) for 1872-1913 and 1925-1938, from Petzina et al. (1978) for 1939-1943 and from the NATO dataset for 1953-1995. Nominal GDP from Jones and Obstfeld (2001) for 1872-1913 and 1925-1938, and from Mitchell (2003) for 1950-1995. GNP from Abelshauser (1998) for 1939-1943. Military burden data 
from Ritschl (2005) for 1914-1918. GDR and DT from Mitchell (2003).

\section{Italy}

ME from Ragioneria generale dello Stato (2011) for 1862-1932; from Zamagni (1998) for 1933-1947; and from the NATO dataset for 19511995 (data for 1948 comes also from Ragioneria generale dello Stato, 2011). GDP from Baffigi (2011). CGR and DT from Mitchell (2003). CIVILEX from Ragioneria generale dello Stato (2011). Exports and Imports data from Mitchell (2003).

\section{Norway}

ME from Banks (1976) for 1860-1913; from the Statistiske Sentralbyra (1948) dataset for 1914-1944; from Statistiske Sentralbyra (1959) for 1945-1948; and from the NATO dataset for 1949-1995. GDP from Grytten (2004). CGR from Statistiske Centralbyra (1926) for 18501913 and from Mitchell (2003) for 1914-1992. DT from Mitchell (2003). Exports and Imports from Mitchell (2003).

\section{Portugal}

ME from Valério (2001) for 1850-1948 and from the NATO database for 1949-1995. GDP from Valério (2001). CGR, DT and CIVILEX from Valério (2001). Exports and Imports from Valério (2001).

\section{Spain}

ME from Sabaté (2013). GDP from Prados de la Escosura (2003). CGR, DT and CIVILEX from Comín and Díaz (2005). Exports and Imports data from Tena (2005). 
Sweden

ME from Schön and Krantz (2012) for 1850-1950 and from the COW dataset for 1951-1995. Exchange rates to convert dollars to Swedish crowns from the Historicalstatistics.org dataset (data collected by Rodney Edvinsson). GDP from Schön and Krantz (2012). CGR from Fregert and Gustafsson (2007) for 1850-1880, and from Mitchell (2003) for 1881-1993. CIVILEX from Fregert and Gustafsson (2007). DT and exports and imports data from Mitchell (2003).

\section{United Kingdom}

ME from Mitchell (1990) for 1850-1913, 1919-1937 and 1946-1948; from Broadberry and Howlett (2005) for 1914-1918; from the COW dataset for 1938-1945; and from the NATO dataset for 1949-1995. Exchange rates to convert dollars to pounds from the Measuring Worth dataset for 1938-1945. Nominal GDP from Measuring Worth. CGR, DT and CIVILEX from Mitchell (2003). Exports and Imports data from Mitchell (2003).

\section{United States}

ME from Carter (2006) for 1850-1948 and from the NATO dataset for 1949-1995. Nominal GDP from Measuring Worth (http://www.measuringworth.com/). CGR, DT and CIVILEX from Carter (2006) and Mitchell (2007). Exports and Imports data from Mitchell (2007). 



\section{ANNEX B. LIST OF MAJOR WARS}

Table 6. Major wars for the whole sample of countries (1850-1995)

\begin{tabular}{|c|c|c|c|}
\hline Countries / War & Period & War & Period \\
\hline \multicolumn{4}{|l|}{ Canada } \\
\hline Saskatchewan Rebellion* & $1884-1885$ & World War II ${ }^{* \#}$ & $1939-1945$ \\
\hline$\underline{\text { World War I*\# }}$ & $1914-1918$ & Korean War*\# & $1950-1953$ \\
\hline \multicolumn{4}{|l|}{ France } \\
\hline Crimean War*\# & $1854-1856$ & World War I*\# & $1914-1918$ \\
\hline$\underline{\text { Franco-Prussian War*\# }}$ & $1870-1871$ & World War II*\# & 1939-1945 \\
\hline \multicolumn{4}{|l|}{ Germany } \\
\hline$\underline{\text { World War I*\# }}$ & $1914-1918$ & World War II*\# & 1939-1945 \\
\hline \multicolumn{4}{|l|}{ Italy } \\
\hline Seven Weeks War* & 1866 & World War II*\# & $1939-1945$ \\
\hline World War I*\# & 1914-1918 & & \\
\hline \multicolumn{4}{|l|}{ Norway } \\
\hline World War II* & 1939-1945 & & \\
\hline \multicolumn{4}{|l|}{ Portugal } \\
\hline$\underline{\text { World War I*\# }}$ & $1914-1918$ & & \\
\hline \multicolumn{4}{|l|}{ Spain } \\
\hline Third Carlist War* & $1872-1876$ & World War II*\# & $1939-1945$ \\
\hline$\underline{\text { Rif Rebellion }}^{\#}$ & 1921-1926 & & \\
\hline \multicolumn{4}{|l|}{ Sweden } \\
\hline World War II*\# & 1939-1945 & & \\
\hline \multicolumn{4}{|l|}{ United Kingdom } \\
\hline Crimean War*\# & $1854-1856$ & World War II*\# & $1939-1945$ \\
\hline Second Boer War*\# & 1899-1902 & Korean War ${ }^{\#}$ & $1950-1953$ \\
\hline World War I*\# & $1914-1918$ & & \\
\hline \multicolumn{4}{|l|}{ United States } \\
\hline American Civil War*\# & 1861-1865 & World War I*\# & 1914-1918 \\
\hline Spanish-American War* & 1898 & World War II*\# & $1939-1945$ \\
\hline American-Philippine War* & 1899-1902 & Korean War*\# & $1950-1953$ \\
\hline
\end{tabular}

Notes: see text for the sources. The wars marked with an asterisk correspond to those conflicts that implied more than 100 per cent of increase in the military burden levels (within a maximum of 5 years). On the other hand, the wars marked with a hashtag correspond to those wars that implied more than 50 per cent of increase in the military burden levels and that kept the ratio above 5 per cent of GDP (again within a maximum of 5 years). The two measures require at least five years in between the wars. When two conflicts are closer in time, only the one with the highest military burden ratio remains in the list. 



\section{ICIP WORKING PAPERS SUBMISSION GUIDELINES:}

\section{International Catalan Institute for Peace (ICIP)}

- The principle purpose of the ICIP is to promote a culture of peace in Catalonia as well as throughout the world, to endorse peaceful solutions and conflict resolutions and to endow Catalonia with an active role as an agent of peace and peace research. The ICIP, seeking consistency between ends and means, is governed by the principles of promoting peace, democracy, justice, equality and equity in relationships between individuals, peoples, cultures, nations and states. It holds the aim of working for human security, disarmament, the prevention and peaceful resolution of conflicts and social tensions, and strengthening the roots of peace and coexistence, peace building and advocacy of human rights.

\section{Objectives of the Publication}

- The ICIP wants to create an open forum on topics related to peace, conflict and security. It aims to open up debate and discussion on both theoretical and contemporary issues associated with the pursuit and maintenance of peace in our world. It strives to connect an eclectic group of voices including career academics, PhD students, NGO representatives, institutional representatives, and field workers and field writers to celebrate ground-breaking and constructive approaches to peace and conflict resolution.

\section{Scope of the Publication (List of Themes)}

- The ICIP is interested in works related to peace, conflict and security research. It aims to provide an innovative and pluralist insight on topics of methodology of peace research, the history and development of peace research, peace education, 
peace-keeping and peace-creating, conflict resolution, human security, human rights, global security, environmental security, development studies related to peace and security, international law related to peace, democracy, justice and equality, disarmament, gender, identity and ethics related to peace, science and technology associated with peace and security.

\section{Audience:}

- The ICP aims to provide accessible, valuable and well-researched material for all those interested in the promotion of peace. Our audience includes fellow academics and researchers, student of peace ands security, field workers, institutional and governmental representatives as well as the general public.

\section{The review process}

- Peer reviewed. Submissions should be sent directly to the series editor (recerca.icip@gencat.cat), who will check whether the paper meets the formal and general criteria for a working paper and will commission a review.

The review procedure is double-blind. The series editor will choose two anonymous reviewers, generally from the Editorial Board, but may also commission an external review from outside the ICIP.

- Reviewers are asked to write a review within a month after having received the paper. Reviews should clearly indicate one of four options: (1) accept without changes; (2) accept with minor changes; (3) allow for resubmission after major changes (4) reject. Options 2 to 4 require some detailed comments. If a paper is accepted (option 1 or 2), reviewers are kindly asked to help authors correct minor linguistic or other errors by making notes in the manuscript. If they use the track changes function for this purpose they should make sure that their comments are anonymized. 


\section{Who may submit working papers?}

- The main criterion for the submission of Working Papers is whether this text could be submitted to a good academic journal.

- ICIP staff and other fellows and visitors affiliated with the ICIP are expected to submit a working paper related to their research while at the ICIP.

\section{Submission System}

- All submissions can be made to the ICIP e-mail address: recerca.icip@gencat.cat with Working Papers - submission in the subject line.

\section{Author Biographical Statement}

- Authors must all provide a short biographical note including full name, affiliation, e-mail address, other contact information if necessary and a brief professional history. This information should be provided on a separate sheet with the title. All other personal references should be removed from the submission to ensure anonymity.

\section{Abstract}

all papers must include English language abstracts (150 words max.)

\section{Keywords}

n A list of four to six keywords is also required.

\section{Language and Style}

- Authors may submit in Catalan, Spanish or English. The submission must be clearly written and easy to follow with headings demarcating the beginning of each section. Submission must in be Arial 11, double spaced and pages must be numbered. 
n Papers should not be longer than 15.000 words (incl. footnotes and references). Longer papers may be returned with a request to shorten them. Papers that require more extensive presentation of data may add these in an appendix that will count separately. Appendices should, however, present data in a reader-friendly and condensed format.

- Papers that will require extensive linguistic editing will not be accepted for review. Minor linguistic corrections (as well as required revisions) suggested by the reviewer must be implemented by the author before the final editing of the paper.

\section{Footnotes}

- Footnotes may be used to provide the reader with substantive information related to the topic of the paper. Footnotes will be part of the word count.

\section{References}

- The Harvard author-date system. In this system, sources are briefly cited in the text, usually in parentheses, by author's last name and date of publication. The short citations are amplified in a list of references in alphabetical list, where full bibliographic information is provided. Bibliographic references must follow The Chicago Manual of Style ( $15^{\text {th }}$ edition). See a Chicago-Style citation quick guide at:

http://www.chicagomanualofstyle.org/tools_citationguide.html Citation generators:

http://www.workscited4u.com/ http://citationmachine.net/ 
2014/4

Disembedding Terrorists:

Identifying New Factors and Models for

Disengagement Research

by Diego Muro, Sandra Levi

(available in english)

\section{4/3}

El Alien Tort Claims Act de 1789;

Su contribución en la protección de los derechos humanos y reparación para las víctimas

by Maria Chiara Marullo

(available in spanish)

\section{$2014 / 2$}

Los programas de reparaciones y los colectivos más vulnerables:

Asháninkas de Selva Central de Perú

by Luis García Villameriel

(available in spanish)

\section{4/1}

Do democracies spend less on the military?

Spain as a long-term case study

(1876-2009)

by Oriol Sabaté Domingo

(available in english)

\section{3/8}

L'est del Congo: arribarà mai el final de la guerra?

by Gérard Prunier

(available in catalan)
2013/7

La transición geográfica de Asia

Central en el nuevo contexto geopolítico

by Elvira Sánchez Mateos, Aurèlia Mañé

Estrada, Carmen de la Cámara, Laura

Huici Sancho

(available in spanish)

$2013 / 6$

New quantitative estimates on long-term military spending in Spain (1850-2009)

by Oriol Sabaté Domingo

(available in catalan and english)

\section{$2013 / 5$}

La memoria histórica, ¿activo transformador de la desigualdad de género?

Análisis crítico del discurso del Centro de Memoria Histórica en Colombia a partir de una mirada de género e interseccionalidad by Marta Grau (available in spanish)

2012/8

Political Humor as a confrontational tool against the Syrian regime.

A study case: Syria, 15th March 2011-15th May 2012 by Blanca Camps-Febrer (available in english) 
INTERNATIONAL

CATALAN

INSTITUTE

\section{FOR PEACE}

TAPINERIA 10, 3rd F. 08002 BARCELONA

T. (+34) 935544270

ICIP@GENCAT.CAT | WWW.ICIP.CAT 